\title{
Second earners and in-work poverty in Europe ${ }^{1}$
}

\author{
H. Xavier Jara ${ }^{2}$ \\ Daria Popova ${ }^{2}$ \\ Correspondence: dpopova@essex.ac.uk
}

\begin{abstract}
Dual or multiple earnership has been considered an important factor to prevent in-work poverty. The aim of this paper is to quantify the impact of second earnership on the risk of in-work poverty and the role of the tax-benefit system in moderating this risk. Our analysis refers to 2014 and employs EUROMOD, the tax-benefit microsimulation model for the European Union and the United Kingdom. In order to assess the role of second earners in preventing in-work poverty we simulate a counterfactual scenario where second earners become unemployed. Our results show that the effect of net replacement rates (i.e. the ratio of household income before and after the transition of second earners to unemployment) on the probability of in-work poverty is negative and statistically significant, but in relative terms it appears to be small compared to the effects of individual labour market characteristics, such as low pay and part-time employment.
\end{abstract}

Keywords: dual earnership; social policy; income distribution; poverty; Europe; second earners

\footnotetext{
${ }^{1}$ This is a peer-reviewed version of the paper accepted at the Journal of Social Policy on 25 March 2020.

${ }^{2}$ Institute for Social and Economic Research, University of Essex, United Kingdom
} 


\section{Introduction}

Poverty and social exclusion in industrialised societies have been traditionally associated with long-term unemployment and household joblessness. To address these issues and to ensure the sustainability of pension and social protection systems in the era of population ageing, many governments across the European Union (EU) and beyond have introduced policies aimed at stimulating labour market participation of the disadvantaged groups such as young, older, lowskilled workers, women and migrants. However, recent evidence shows that in today's labour market having a job might not in itself guarantee freedom from poverty for the employed and their households. Many EU countries have experienced a rise in in-work poverty rates in recent decades (Marx and Nolan 2012; European_Commission 2016; Eurofound 2017).

In-work poverty is related to precarious employment, including low pay, low work intensity, temporary employment, employment in some sectors of the economy (e.g. service sector) and self-employment (Lohmann 2009; Frazer and Marlier 2010; Van Lancker 2011; Maitre, Nolan et al. 2012; Horemans and Marx 2013; Ray, Sissons et al. 2014; Broughton, Green et al. 2016; McKnight, Stewart et al. 2016; Lohmann and Marx 2018; Sissons, Green et al. 2018). Nevertheless, while these labour market characteristics are measured at an individual level, inwork poverty is measured at a household level. In other words, an individual is considered as working poor if they are in work (individual level) and their equivalized household income is below the national poverty line (household level). Therefore, characteristics such as the number of children and the labour market status of other adults in the household have been shown to play a major role. As a result, not all precarious workers live in poor households, and not all poor households contain precarious workers. From a policy perspective, in-work poverty patterns are influenced by a large number of institutional factors and the structure of the labour market. Among those, the key to providing in-work poverty reduction is the generosity of the 
transfer system, e.g. replacement rates of unemployed household members and cash benefits for families (Allègre 2008; Lohmann 2009).

In this paper we focus on a specific group of earners - second earners in multi-earner households. We define the primary or main earner as the person in the household with the highest earnings from work. The second earner is defined as the employed partner of the primary earner or, if the partner is not in work, as the person with the second highest earnings in the household. We seek to quantify the effect of second earners' employment in preventing in-work poverty in the EU member states and the United Kingdom (UK), and the role of the tax-benefit systems in moderating this risk. Following Eurostat we define in-work poverty as the state when individuals are simultaneously in work and at risk of poverty, i.e. their equivalised ${ }^{1}$ household disposable income is below the risk-of-poverty threshold, which is set at $60 \%$ of the national median equivalised disposable income.

To assess the role of second earnership in preventing in-work poverty, we use regression analysis, and pre-post analysis in combination with microsimulation techniques. In other words, we assess what in-work poverty would be if secondary earners were unemployed. More precisely, we use EUROMOD, the European tax-benefit microsimulation model (Sutherland and Figari 2013), and microdata from the European Statistics on Income and Living Conditions (EU-SILC) and the Family Resource Survey (FRS) for the UK. The analysis in this paper refers to 2014 policies in all countries.

The contribution of this study is twofold. First, we analyse the association between second earnership and in-work poverty in the EU and the UK using regression analysis. Second, we use a pre-post analysis to determine the contribution of second earners in preventing in-work poverty. Our strategy consists of simulating a counterfactual scenario under which second earners become unemployed and assessing how this transition would affect household incomes and in-work poverty, as compared to the status-quo (baseline) situation. By using 
microsimulation techniques, we can assess the impact of this transition on poverty net of the effects of tax-benefit policies which are targeted at moderating income shocks due to unemployment. We perform regression analyses on a pre- and post-transition sample of workers in multiple-earner households in order to disentangle the impact of the individual, household- and policy-related characteristics on the probability of in-work poverty. Given the nature of our simulations, the results presented in this paper should be interpreted as first-order effects before any behavioural adjustment occurs. Nevertheless, this analysis is relevant for the research question as it provides a transparent quantitative assessment of how important the second earners' employment is in lifting the working household above the poverty line in European countries.

The remainder of this paper is structured as follows. Section 2 summarises previous research on in-work poverty and second earners in Europe. Section 3 describes the data and the methodology used to quantify the effect of second earnership and government policies on inwork poverty. Section 4 presents and discusses the results of our analysis. Section 5 concludes.

\section{In-work poverty and secondary earners: literature review}

Since the late 1990s many European countries' employment policies have become increasingly focused on getting more people into jobs by promoting and enforcing labour market activation measures, such as training and skills development programmes for the unemployed, the sanctioning of individuals not looking for jobs by withdrawing their benefits, in-work benefits, subsidised employment, etc. Raising employment rates to $75 \%$ of the population aged 20-64 years has been declared one of the 2020 EU targets. At the same time, the post-industrial economy has been moving towards higher job polarisation, i.e. a growth in employment in the highest-skilled (managerial and professional) and lowest-skilled occupations (unskilled work 
in service sector) and a decline in demand for individuals with medium skills (Goos and Salomons 2009; OECD 2015). As wage inequality has been on the increase, for the individuals at the bottom of the wage distribution even full-time employment might no longer guarantee a poverty-free existence. As a result, many EU countries have experienced a rise in in-work poverty rates (Marx and Nolan 2012; European Commission 2016; Eurofound 2017; Lohmann and Marx 2018).

Measuring in-work poverty implies defining 'work' and 'poverty', respectively. The research on in-work poverty in Europe has been underpinned by different national academic traditions of measuring employment and poverty (for a detailed overview see Eurofound (2017)). In particular, there is no consensus in the literature about a common definition of 'worker'. Although most studies use information on labour market activity over the year to define work, the duration of activity over the year used to define a person as a 'worker' varies across studies (Ponthieux 2010). At the EU-level, the working poor are defined as employed individuals living in households with equivalised disposable income below $60 \%$ of the national median (European Commission 2015). An individual is considered as employed if he/she worked for at least 15 hours a week for more than a half of the past year, that is, his/her typical situation is to be working. Thus, in-work poverty rate is computed as the percentage of individuals who are in work and at risk of poverty among those who are currently in work. Note that the concept of the working poor is different from (although often conflated with) the low-paid worker concept. Low-paid workers are defined by Eurostat as employees who earn two thirds or less of national median gross hourly earnings. Hence, there might be low-paid workers who are not poor, and vice versa.

The way in-work poverty is defined complicates the interpretation of this measure and the identification of its underlying causes. Since individual- and household-level information is combined within this measure, the poverty status of an individual depends not only on his/her 
own employment characteristics, but also on other household members' labour market status and on other household characteristics such as the number of dependent children. In addition, the EU definition is restrictive in measuring employment. It results in selecting individuals who are mostly in stable employment, and consequently emphasises the household situation of workers as the prominent factor of poverty risk, while the role of the individual labour market characteristics (such as precarious employment) is downplayed (Ponthieux 2010).

Whatever the metric used, in-work poverty has been shown to be strongly related to precarious employment characteristics, among which the most important are low pay, low work intensity, temporary employment, employment in some sectors of economy such as the service sector, and self-employment (Lohmann 2009; Frazer and Marlier 2010; Van Lancker 2011; Maitre, Nolan et al. 2012; Horemans and Marx 2013; Ray, Sissons et al. 2014; Broughton, Green et al. 2016; McKnight, Stewart et al. 2016; Lohmann and Marx 2018; Sissons, Green et al. 2018). However, their impact on poverty greatly depends on the mechanisms shaping these types of labour market participation patterns. For example, part-time employment does not necessarily result in in-work poverty unless it represents an inferior form of employment (e.g. due to low pay and job insecurity) (Horemans and Marx 2013). The key characteristic of almost all types of precarious work is that they are highly gendered. It has been shown that women tend to forgo better paying, full-time jobs mainly due to their caring responsibilities, while men are more likely to do so for other reasons (OECD 2011).

At the same time, the effect of individual labour market characteristics on poverty is moderated by household composition. Dual or multiple earnership is one of the most important factors that lifts families out of poverty (Marx and Nolan 2012). If a precarious worker is the second earner in the household (which is typically the case for coupled women), their in-work poverty risk might drop to a very low level due to the contribution of the main earner to household income (Ponthieux 2018). Hence, in this case precarious job characteristics may be the result 
of choices of activity made in the context of intra-household division of labour. In contrast, precarious workers who are the sole earners in their households are at a substantial risk of poverty, especially if they have dependent children to support. Over the last few decades, all European countries have experienced growth in dual earnership due to increased female labour force participation, albeit with some variation across welfare regimes. In particular there is a higher prevalence of such households in Scandinavian countries and lower prevalence in Southern Europe (Andre $\beta$ and Lohmann 2008). Since dual earner families have become the most common model among couples in Europe, the relative poverty thresholds are being increasingly defined by two-earner households, which further deteriorates the position of oneearner households (Marx and Nolan 2012).

Apart from individual and household characteristics, several studies have looked at the significance of institutional, labour market and demographic factors at the macro-level for inwork poverty. According to Allègre (2008), social spending as a proportion of GDP is the main factor contributing to lower in-work poverty rates in Europe. Similarly, Lohmann (2009) showed that the generosity of the transfer system (replacement rates in case of unemployment and cash benefits for families) is key to explaining both in-work poverty rates and in-work poverty reduction. Filandri and Struffolino (2019) found a positive association between involuntary part-time employment rate and household in-work poverty and a negative relationship between female labour market participation rate and in-work poverty. In terms of differences across the welfare regimes, Crettaz and Bonoli (2010) argue that the characteristics of in-work poverty found in socio-democratic and conservative regimes (in their study represented by Sweden and Germany) are less detrimental than those found in South-European and liberal regimes (represented by Spain and the United States). In the former, in-work poverty is driven by low pay and concentrated on young, single and childless adults, while fulltime workers have low in-work poverty rates. In the latter, in-work poverty appears to be driven 
by a combination of low labour market attachment, low pay and the presence of children. This highlights the crucial role played by government tax-benefit policies in protecting children in working families.

At the same time, it is important to stress that the design of tax-benefit systems has both direct and indirect effects on in-work poverty. While generous direct transfers to low income households with children reduce in-work poverty, they might simultaneously weaken individual incentives to undertake paid work or to increase hours of work for all household members. A high tax burden may produce a similar negative effect on labour market participation (Adam, Brewer et al. 2006). Empirical studies find that labour supply elasticity is higher for low-income earners, in particular women with children, therefore tax-benefit policies tend to have a disproportionally high negative effect on the employment outcomes of second earners (Evans and Harkness 2010; Rastrigina and Vereshchagna 2015; Thomas and O'Reilly 2016).

\section{Methods and data}

Our study uses standard pre-post analysis (e.g. see Moller, Huber et al. (2003)) in combination with microsimulation techniques in order to assess the role of second earners in preventing inwork poverty. More precisely, we simulate a counterfactual scenario where second earners become unemployed, and assess the effect of such transitions on in-work poverty in all EU countries and the UK. We choose to model the transition to unemployment (rather than inactivity) as it seems to be the most relevant scenario for individuals who currently choose to work. This section provides the definitions of in-work poverty and second earners used in our analysis. We then describe EUROMOD, the European tax-benefit microsimulation model, and 
the data. Finally, we present the methodology used to assess the impact of secondary earners on in-work poverty.

\subsection{Definitions of in-work poverty and second earners}

In our analysis, for comparability purposes, we use the EU-level definition of in-work poverty, according to which individuals are considered as working poor if they are currently in work and at risk of poverty, i.e. their equivalised disposable income is below the risk-of-poverty threshold set at $60 \%$ of the national median equivalised disposable income. The percentage of working poor is calculated with respect to the total number of individuals who are in work. Individuals are considered to be in work if they have declared themselves employed or selfemployed for at least 7 months in the year preceding the survey.

We further define primary or main earner as the person in the household with the highest earnings from work. The second earner is then defined as the employed partner of the primary earner. If the primary earner has no partner or the partner is not in work, the second earner is defined as the person with the second highest earnings.

\subsection{EUROMOD and the data}

Our analysis makes use of EUROMOD, the European tax-benefit microsimulation model. EUROMOD covers all EU member states and the UK and simulates, in a fully comparable manner, cash benefit entitlements and direct personal tax and social insurance contribution liabilities on the basis of the tax-benefit rules in place and representative household microdata. EUROMOD has been validated at both the micro- and the macro-level and has been tested in numerous policy-relevant research applications (Sutherland and Figari 2013). 
The input data for EUROMOD comes from EU-SILC which was designed to be the main statistical source to monitor living standards and social inclusion in the EU in a harmonised manner. EU-SILC contains detailed information on different income sources as well as household and individual characteristics, which are essential for the purpose of microsimulation. Nevertheless, EU-SILC also suffers from some limitations in terms of its applicability for cross-country tax-benefit simulations (Figari, Iacovou et al. 2012). First, some countries in EU-SILC record net income data, whereas the starting point for tax-benefit simulations is gross income. In such cases, a net-to-gross income conversion needs to be performed. Second, the reference period for income is the calendar year prior to the interview, while labour market characteristics are measured at the time of interview. There is therefore a mismatch between income data and labour market information. For this reason, we use the number of months in work over the calendar year to define the status of 'worker' in our definition of in-work poverty. Third, the source of information used to collect income data differs across countries. Some countries use survey-based income data and in others, income is based on administrative registers. Survey-based income data are, in general, more prone to issues of underreporting or misreporting, which could result in an upward bias in in-work poverty rates (Jäntti, Törmäletho et al. 2013). Despite these shortcomings, EU-SILC remains a unique resource and the main one for cross-national comparative research on income poverty and inequality in the EU countries and the UK.

In this study we use the 2015 EU-SILC (the latest data year available at the time of writing), which includes income information from the previous year (2014); the 2014 EU-SILC for Germany (with income information from 2013) and the Family Resource Survey 2013/2014 which is a part of EU-SILC for the UK. We take the 2014 tax-benefit policies (reflecting the situation as of June $30^{\text {th }}$ ) as a starting point to ensure that the policy year matches the income reference year in the data. ${ }^{2}$ In the case of Germany, market incomes and non-simulated tax- 
benefit instruments in the data are adjusted to 2014 levels using source-specific updating factors.

Our sample of interest consists of all earners aged 18-64 years in each country. We first look into the determinants of second earnership and in-work poverty by means of multivariate logistic regressions based on a pooled dataset for all countries with country fixed effects, where dummy variables control for the effect of unobserved factors that are shared within each country. We then analyse the effect of second earnership on in-work poverty by simulating transitions of second earners from work into unemployment and evaluating the change in inwork poverty and the extent to which it is moderated by the tax-transfer system. The latter approach is discussed in the next section.

\subsection{Assessing the impact of second earners and tax-benefit policies on in-work poverty: a pre-post analysis}

In order to assess the role of second earners in preventing in-work poverty we use a standard pre-post analysis. The method consists of creating a counterfactual scenario in which we simulate transitions from work (employment or self-employment) into unemployment for all second earners in our data, re-calculate their household disposable income under their new labour market status and assess how such a transition would affect in-work poverty.

The effect of transitions to unemployment in our analysis is simulated in the following way. First, disposable income and in-work poverty status are calculated before the transition to unemployment takes place (baseline scenario). Then, in the counterfactual scenario, we set individual earnings of all second earners in our data to zero, use EUROMOD to simulate all social benefits and taxes they would become entitled to, and re-calculate their household disposable income under unemployment ${ }^{3}$. Finally, in-work poverty status after the transition 
to unemployment is recalculated and compared to in-work poverty status in the baseline scenario.

This is a static analysis that does not take into account any behavioural changes. In particular, we assume that, following the entry to unemployment of an earner in the household, the labour market status of other household members remains unchanged (i.e. no behavioural labour supply responses). However, it is relevant for our research question and has a number of advantages from the methodological point of view. In contrast to the existing studies of the impact of public policies on in-work poverty that look at the role of institutional indicators at the macro-level (e.g. Lohmann (2009)), the microsimulation approach enables us to obtain estimates that are representative for the whole population and to study the distribution of welfare provisions at the micro-level. Second, simulations of unemployment transitions across the whole population of second earners helps us avoid the problem of small samples and selfselection in survey data, where we observe second earners who have already become unemployed and their households have adjusted their behaviour to the new circumstances.

We use the following indicators to measure the effects of taxes and benefits in terms of stabilising incomes in unemployment (measure of the policy output) and reducing income poverty for working individuals (the outcome measure). The net replacement rate (a policy output indicator) is an individual-specific indicator defined as the ratio between household disposable income when the person is unemployed to household disposable income when the person is in work, assuming that the labour market status of other household members remains unchanged. Full take-up of benefits is assumed in the event of unemployment. In this sense, our indicator captures the intended effect of tax-benefit policies. The outcomes are captured by comparing the pre- and post-transition poverty status using a fixed (pre-transition) poverty line. Individuals are considered poor if their equivalised disposable income after the transition falls below a poverty line fixed at $60 \%$ of the median equivalised disposable income in the 
original population before the transition. These indicators are used to assess the impact of second earners on in-work poverty using a regression analysis.

\section{Empirical results}

\subsection{Second earnership and in-work poverty in Europe: prevalence and characteristics}

We start the discussion of the results by looking at the prevalence and characteristics of second earners in Europe. Figure 1 shows the breakdown of the total number of earners by earnership status in the household. The number of those who are in work among working age individuals varies a great deal (from $90 \%$ in Sweden to only $54.4 \%$ in Greece). The relevance of dual or multiple earnership in European countries is depicted by the fact that among all individuals who are in work the overwhelming majority lives in households with at least 2 earners (73\% on average, ranging from $82 \%$ in Slovakia to $60.4 \%$ in Greece). Second earners constitute on average about a third of all earners in all countries, with little cross-country variation (their share ranges from $33.5 \%$ in Portugal to $28.3 \%$ in Greece).

\section{Figure 1 about here}

On average in the EU and the UK second earners in multiple-earner households are predominantly women $(64.1 \%)$, coupled with main earners $(75.4 \%)$, earning significantly less than the main earners in their households (Figure A1, Supplemental Material). On average, the monthly earnings of second earners amount to $56.8 \%$ of earnings of the primary (main) earner, and this ranges from $46.5 \%$ in Germany to $70.4 \%$ in Romania. 
The analysis of individual characteristics of second earners provides tentative explanations as to why their earning capacity is lower than that of the main earners. In most countries, second earners are more likely to have characteristics related to precarious employment as compared to main earners, i.e. they are more likely to be in low-skilled occupations (i.e. an occupational status below 3 on the International Standard Classification of Occupations (ISCO) scale), lowpaid (i.e. hourly earnings falling below two-thirds of median hourly earnings of full-time fullyear workers in the country) and to work part-time (i.e. less than 30 hours per week) (Figure A2, Supplemental Material). In 14 out of 28 countries, second earners are more likely to be self-employed than main earners, with the gap of 5 p.p. and higher in Greece, Slovenia and Romania. Out of the above four employment characteristics, the highest gap between second and main earners is observed in terms of low pay and part-time employment.

Figure 2 depicts the prevalence of in-work poverty in the EU and the UK. The results show a great deal of variation across countries, with in-work poverty rates ranging from less than $3 \%$ of the working population in Belgium and Finland up to a high of $17 \%$ in Romania. In general, it appears that all West European countries have lower rates of in-work poverty compared to Southern Europe. East European countries fall into two clusters. The first one comprises countries with low in-work poverty rates similar to those in Western Europe (Czechia, Slovakia, Croatia and Slovenia). The rest of East European countries form a cluster where inwork poverty rates are as high as in Southern Europe. In-work poverty rates of second earners in all countries are either lower than or equal to those of main earners, because the latter group includes sole earners. This confirms the results of previous studies of multiple earnership and in-work poverty in the EU (Maitre, Nolan et al. 2012; Horemans and Marx 2013; European Commission 2016; Eurofound 2017). 
Next, we turn to the determinants of in-work poverty. Table 1 shows a logistic regression of in-work poverty status for all earners aged 18-64 years, on a pooled dataset of 28 countries with country fixed effects. To measure the effects of the earner's status within the household, we have added a categorical predictor showing whether an individual is the main earner, second earner, other (third and subsequent) earner, with sole earners being the reference category. Following the literature, we included the following socio-demographic predictors: sex (female or not), age (in years), age squared, being partnered, the number of children aged 0-3 years, 35 years, 6-12 years and 13-17 years. Labour market-related characteristics used as predictors include: low skill level (i.e. an occupational status below 3 on ISCO scale), self-employment, part-time employment (i.e. working less than 30 hours per week) and low pay (i.e. hourly earnings falling below two-thirds of median hourly earnings of full-time full-year workers in the country). Additionally, to control for household economic resources, we have included characteristics such as the number of earners in the household, home ownership status (tenant or not) and financial capital (in a logarithmic form). The descriptive statistics for the variables used in the analysis are presented in Table A1, Supplemental Material. We have estimated two models: the baseline model with all the above-mentioned predictors (Model 1) and the model with the same predictors and interactions between the earner's status (main earner, second earner or other earner) and their individual characteristics (Model 2).

Model 1 shows that as far as the earner's status in the household is concerned, compared to sole earners (the reference category), main earners in households with multiple earners have a $4.1 \%$ lower probability of being poor while working. Being a second or other earner in a household with multiple earners reduces the chances of being working poor by more than $10 \%$. With regard to other individual-level characteristics we control for in this model, we see that women are slightly less likely to be poor while working compared to men, while partnered 
individuals are more prone to in-work poverty compared to non-partnered ones. The effect of age appears to have a U-form shape, i.e. the probability of in-work poverty first decreases with years of working experience and then increases for older workers. However, the relative impact of these demographic characteristics on the probability of in-work poverty is small (below 3\%). As also predicted by previous research on in-work poverty, household-level characteristics matter for explaining in-work poverty. The poverty risk increases with the number and age of children and reduces with the number of workers in the household. Not owning a home (being a tenant) is positively associated with in-work poverty, while having higher financial capital is a poverty-reducing characteristic. Yet again the impact of these variables on the probability of in-work poverty appears to be much smaller than that of individual labour market characteristics. Part-time employment and low pay are particularly important. The former increases the probability of in-work poverty by $8 \%$, the latter - by almost $12 \%$. Being a lowskilled or a self-employed worker increases the probability of in-work poverty by 3.5 and $4.8 \%$, respectively.

After adding interactions of all personal characteristics ${ }^{4}$ with earnership status (Model 2), we can see that the estimated impact on in-work poverty of being a woman, having a part-time job and even having a low paid job, is negative, or poverty-reducing for second earners, as opposed to the impact of these characteristics on main earners. Overall the impact of all personal employment characteristics on in-work poverty for individuals living in households with multiple earners is much smaller than for sole earners. In other words, our analysis shows that multiple earnership serves as an important poverty-preventing factor for individuals with precarious employment characteristics. 


\subsection{The impact of second earners on in-work poverty in Europe: a pre-post analysis}

We now move on to our pre-post analysis. In order to quantify the impact of second earners on in-work poverty in Europe, we compare the situation before the transition (baseline scenario) and the situation after the transition of second earners into unemployment (counterfactual scenario).

Importantly, the pre-post analysis in combination with EUROMOD enables us to assess the impact of government policies aimed at preventing income losses due to unemployment at the individual level, which we measure with the indicator of net replacement rates (NRRs), or the ratio of the post-transition to pre-transition household disposable income. The size of NRRs is determined both by the generosity of tax-benefit systems towards the unemployed and their families (unemployment and other benefits that the family or the household might be eligible for) and by market incomes of other household members, particularly so for second earners. The decomposition of NRRs of main and second earners is shown in Figures A3 and A4, Supplemental Material.

\section{Figure 3 about here}

Figure 3 shows mean NRRs of second earners as a whole (orange circles), as well as mean NRRs of second earners by quintiles of the pre-transition individual earnings in each country. The countries are ordered by mean net replacement rates of all second earners in the sample. NRRs at the mean vary from $75.6 \%$ in Malta to $93.4 \%$ in Luxembourg, with the average at 83\% across countries. NRRs are highest in Nordic and continental West European countries, 
where unemployment benefits play a particularly important role (see Figure A4, Supplemental Material). Anglo-Saxon and South-European countries present the highest within- country variation of NRRs of second earners, Portugal being the exception. NRRs are particularly high at the bottom of the distribution (the bottom earnings quintile) due to the small contribution of earnings from second earners to household disposable income, but they also depend on the generosity of the tax-benefit system (e.g. larger in Nordic countries). Second earners from the top quintile benefit from the highest ( $90 \%$ and over) net replacement rates in Portugal, Luxembourg and France.

Figure 4 shows the extent to which in-work poverty would increase if all second earners were to become unemployed, given that their lost earnings would be partially replaced by unemployment benefits and other tax-benefit instruments they are eligible for. ${ }^{5,6}$ In all countries, in-work poverty would increase substantially (by 4.5 p.p.), however, the effect of this transition varies widely across countries. In Greece, Ireland and Finland, in-work poverty would increase by less than 2 p.p. following an entry of all second earners into unemployment. Hungary and Poland would experience the largest increase in in-work poverty of over 8 p.p.

The reasons for the cross-country differences in the in-work poverty changes depend on a combination of factors, such as the pre-transition level of in-work poverty, the prevalence of second earners in the country, the level of earnings of second earners and their household members and the design of the tax-benefit system, i.e. the level of replacement of second earners' income once they become unemployed (captured by NRRs). Figure A5 (Supplemental Material) plots the change in in-work poverty rates due to transition of second earners into unemployment against mean NRRs of second earners. As expected, these two indicators are negatively correlated; in countries where second earners have high NRRs, the change in inwork poverty is smaller and vice versa. Yet NRRs is not the only factor affecting the change 
in in-work poverty. In order to assess the relative contribution of various factors to in-work poverty rates we will need to apply a regression analysis.

\section{Figure 4 about here}

Having analysed how the transition of second earners affects aggregate indices of in-work poverty, we turn to analyses of the pre- and post-transition in-work poverty status for main and other earners in households with multiple earners. Figure A8 of the Supplemental Material presents the distribution of their in-work poverty statuses before and after the transition. On average across countries, $4.4 \%$ of earners in multi-earner households would fall into poverty as a result of a transition of second earners to unemployment. The effect of the transition would be particularly high in countries such as Hungary, Poland and Slovakia, where over $7 \%$ of earners in multi-earner households would fall into poverty. The figure further highlights the prevalence of the group of earners for whom multiple earnership does not prevent in-work poverty (those who are poor before and after the transition). In general the size of this group is small (4\% on average across countries), but not negligible in some countries (e.g. in Romania it amounts to $14.2 \%$ ).

Table 2 shows the results of the regression analyses of the probability of pre- and post-transition in-work poverty for earners in multi-earner households, using the same set of predictors as in the models for all earners presented in Table 1. In addition, simulating the transition enables us to measure the moderating effect of the tax-benefit systems on in-work poverty. This is done by introducing NRRs of second earners as a predictor of post-transition in-work poverty of all other earners in their households (Model 2). In contrast to previous studies, we measure the effect of government policies at the individual level, which enables us to take into account the 
level and the distribution of government provisions across the whole population of workers. It should be noted that NRRs capture not only the generosity of the tax-benefit system towards the unemployed but are also influenced by the earnings (or more generally market income) of other household members. The regression analysis aims at controlling for these factors in order to assess the net impact of the tax-benefit system on in-work poverty. In Model 3 we have restricted the sample to individuals who were not poor before the transition of secondary earners into unemployment. The descriptive statistics for the variables used in these regression models are presented in Table A3, Supplemental Material.

Looking more closely at the covariates associated with post-transition poverty risk in Table 2 (Models 2 and 3) we can see that the direction of the effects of personal and household characteristics remains broadly the same as in the pre-transition model (Model 1). However, the size of the effects becomes significantly larger in post-transition Model 2. The exceptions are "age" and "partnership status" which are no longer statistically significant. Low pay and part-time employment continue to be the most important predictors, increasing the probability of in-work poverty by 13.5 and $8.2 \%$, respectively. NRRs of secondary earners have a statistically significant poverty-reducing effect, but it appears to be small compared to the effects of individual employment characteristics, i.e. 10 p.p. increase in NRRs reduces the probability of poverty just by $1.4 \%$.

In Model 3 we have removed all individuals from the sample who were already classified as the working poor before moving second earners into unemployment in order to target those who could become poor after the simulated transitions. The direction of the effects of personal and household characteristics is similar to Model 2 but with a reduction in their predictive power, which is expected, as these variables are more correlated with the status of being working poor in the baseline and those individuals are not part of the sample in Model 3. On the other hand, we observe an increase in the size of the effect of NRRs (a 10 p.p. increase in 
NRRs would result in a $3 \%$ reduction in the probability of in-work poverty, which is twice as high compared to Model 2). In other words, for those who were not working poor before the transition, the unemployment of second earners becomes the main driving factor of poverty, thus NRRs play a more important role.

\section{Table 2 about here}

\section{Conclusion}

In-work poverty rates are the result of complex interactions between individual- and household-level characteristics and institutional and labour market structures. Among these factors, dual earnership and the design of tax-benefits systems have been regarded as the most influential determinants of in-work poverty rates. This paper aimed to quantify the impact of second earnership on the risk of in-work poverty in Europe and the role of the tax-benefit systems in moderating this risk.

Our analysis provides a number of interesting findings. First, we confirm that the contribution of second earners to household income serves as an important factor to prevent in-work poverty. Under a counterfactual scenario, where all second earners become unemployed, the in-work poverty rate in the EU and the UK would go up from 7.4 to $11.9 \%$ of the working population, or by $60 \%$ in relative terms. Second, dual earnership appears to be a particularly important poverty-preventing factor for individuals with precarious employment characteristics (especially for part-time and low-paid workers), as the impact of all personal employment-related characteristics on in-work poverty for individuals living in households

with $2+$ earners is much smaller than for sole earners. Third, tax-benefit policies play a 
significant role in mitigating in-work poverty in the event of unemployment of second earners. Contrary to previous studies that have proxied the effect of tax-benefit policies by institutional macro-level indicators, we use individual-specific indicators of net replacement rates (i.e. the percentage of equivalised household disposable income that is replaced by government transfers, or by a reduction in taxes, in case of unemployment) and show that they have a negative and statistically significant effect on the probability of in-work poverty. The effect appears, however, small relative to the effects of individual labour market characteristics, such as low pay and part-time employment.

From a policy perspective, our results convey a number of relevant messages. Overall, although part-time or low-paid employment of second earners results in a higher poverty risk than standard full-time employment, the risk goes up dramatically in the case of non-employment of second earners (or to be more precise, in the case of sole earnership). This implies that a successful policy response to in-work poverty problems should primarily emphasise policy measures reducing difficulties for second earners (who are mostly women), to balance work and caring responsibilities, as well as redistributive policies supporting the work incentives of second earners (e.g. in-work benefit schemes that are means-tested on household incomes). Employment policies, on their own, cannot be deemed sufficient. Our analysis shows that in some countries in-work poverty is also prevalent among individuals living in multiple-earner households. These are households where workers are in low-paid and/or low-intensity jobs. More attention deserves to be paid to designing policies aimed at improving living standards for this particular group of workers. Finally, given the changing nature of the labour markets, where atypical forms of employment such as part-time, temporary jobs and self-employment have become more prevalent, the adequacy of tax-benefit systems to protect all types of workers in the event of different risks, such as unemployment, should be evaluated. The latter 
point seems particularly relevant in the context of the signing of the European Pillar of Social Rights in November 2017.

Further research could extend the analysis presented in this paper in several dimensions. First, for comparative purposes in this paper we opted for using the EU-level definition of in-work poverty. However, there seems to be a need for testing different definitions. For instance, it would be interesting to define in-work poverty purely at the individual level as suggested by Ponthieux (2010). The latter would allow gender inequalities to be highlighted as these are largely erased with the conventional household-level approach to poverty risk. Second, we concentrated on the effect of second earners' entry into unemployment. An alternative way to assess the effect of second earnership on in-work poverty is to focus on the impact of entries into employment of working-age individuals who are out of work. The effects of such an approach depend, however, on the assumptions about these individuals' employment preferences, level of earnings and hours of work (among others) they would face when entering employment. Third, our analysis did not take into account potential adjustments in the behaviour of other household members after the entry of the second earner into unemployment. Structural labour supply models could be used to predict potential reactions of household members following unemployment shocks. Alternatively, one could also evaluate the amount of additional labour supply needed to compensate the loss of employment by second earners. Finally, our analysis has focused on cash programmes, omitting non-cash policies, which might play an important role in preventing in-work poverty. However, imputing information on noncash policies in survey data across countries in a consistent way remains a challenging task. The above-mentioned issues were beyond the scope of this paper, which focused on providing a comprehensive quantitative cross-county assessment of how important second earners' employment and government policies are in lifting individuals in work above the poverty line, 
which is relevant both in terms of employment activation policies and social protection

programmes in Europe.

Acknowledgements: We are grateful to Holly Sutherland, Mike Brewer, the editor and two anonymous reviewers at Journal of Social Policy for their valuable comments. The results presented here are based on EUROMOD version H1.0. EUROMOD is maintained, developed and managed by the Institute for Social and Economic Research (ISER) at the University of Essex, in collaboration with national teams from the EU member states. We are indebted to the many people who have contributed to the development of EUROMOD. The process of extending and updating EUROMOD is financially supported by the European Union Programme for Employment and Social Innovation 'Easi' (2014-2020). The results and their interpretation are the authors' responsibility.

${ }^{1}$ Here and throughout the paper, household disposable income is equivalised using the modified OECD equivalence scale.

${ }^{2}$ Relative to 2013, tax-benefit policies introduced in 2014 had on average a small effect on household incomes across European countries. Household disposable income changed on average by less than 1 percent in most countries, as a result of changes in tax-benefit policies (EUROMOD, 2016). Hence, there were no major policy changes preceding our reference year. However, it is important to bear in mind that although by 2014 most European countries had recovered (or were in the process of recovering) from the financial crisis, the extent and duration of the recession varied widely across countries. As such, 2014 still represented a year with high unemployment in many countries, which could influence the levels of in-work poverty in our analysis.

${ }^{3}$ Other relevant labour market variables entering the simulations are adjusted to reflect the corresponding change in their labour market situation e.g. labour market status set to unemployment, hours of work set to zero, etc.

${ }^{4}$ Interactions of earnership status with age and age squared were dropped because they were not statistically significant.

${ }^{5}$ Apart from the main counterfactual scenario where all second earners are moved into unemployment, we have also assessed the effect of smaller unemployment shocks, whereby 5\%,10\%, 25\%, and 50\% of second earners with the highest probability of unemployment risk would lose their jobs. The probability of unemployment was calculated from a probit model of unemployment experience in the past year as a function of a set of individual, household and job characteristics for a sample of people in work in the EU-SILC data. These results show that the impact of partial transitions on in-work poverty is very small (Figure A6, Supplemental Material). The reason behind the negligible effects of smaller unemployment shocks is that second earners with the highest probability of becoming unemployed (i.e. those transitioning into unemployment first) are characterised by low pay and their contribution to household disposable income is minor.

${ }^{6}$ Given the limitations of the EU definition to measure employment, which selects individuals who are mostly in stable employment (Pontieux, 2010), we ran a sensitivity analysis (SA), where the working poor were defined as individuals who had at least one month of employment over the past year, living in households with equivalised disposable income below $60 \%$ of the national median. These results are presented in Figure A7, Supplemental Material. Under our SA, in-work poverty increases only marginally in most countries, except in Denmark, Spain, Finland, Hungary, the Netherlands and Sweden, where the increase is above 2 p.p. Most importantly, the difference between the post- and pre-transition in-work poverty rates in both scenarios remains very similar, which confirms the robustness of our results in terms of the effect of second earnership on in-work poverty. 


\section{References}

Adam, S., M. Brewer, et al. (2006). Financial work incentives in Britain: comparisons over time and between family types. IFS working paper WP06/20.

Allègre, G. (2008). Working poor in the EU: an exploratory comparative analysis. Working Paper No 2008-35, OFCE - Centre de recherche en économie de Sciences Po.

Andre $\beta$, H. J. and H. Lohmann, Eds. (2008). The working poor in Europe: Employment, poverty and globalisation. London, Edward Elgar.

Broughton, A., M. Green, et al. (2016). Precarious employment in Europe: Patterns, trends and policy strategies, European Parliament.

Crettaz, E. and G. Bonoli (2010). Why are some workers poor? The mechanisms that produce working poverty in a comparative perspective. Working Papers on the Reconciliation of Work and Welfare in Europe. REC-WP 12/2010.

Eurofound (2017). In-work poverty in the EU. Luxembourg, Publications Office of the European Union.

European_Commission (2015). Portfolio of indicators for the monitoring of the European strategy for social protection and social exclusion - 2015 update. Brussels, European Commission.

European_Commission (2016). Low pay and in work poverty: Preventative measures and preventative approaches. Luxembourg, Publications Office of the European Union.

Evans, M. and S. Harkness (2010). "The impact of the tax and benefit system on second earners." Journal of poverty and social justice 18(1): 35-51.

Figari, F., M. Iacovou, et al. (2012). "Approximations to the Truth: Comparing Survey and Microsimulation Approaches to Measuring Income for Social Indicators." Social Indicators Research 105(3): 387-407.

Filandri, M. and E. Struffolino (2019). "Individual and household in-work poverty in Europe: understanding the role of labor market characteristics." European Societies 21(1): 130157.

Frazer, H. and E. Marlier (2010). In work poverty and labour market segmentation in the EU: Key Lessons. Synthesis Report. EU Network of Independent Experts on Social Inclusion, DG Employment, Social Affairs and Inclusion. Brussels.

Goos, M. and A. Salomons (2009). "The polarization of the European labor market." American Economic Review 99(2): 59-63.

Horemans, J. and I. Marx (2013). In-work poverty in times of crisis: Do part-timers fare worse? ImPRovE Discussion Paper No. 13/14. Antwerp.

ILO (2012). International Standard Classification of Occupations: ISCO-08. Geneva, International Labour Office.

Jäntti, M., V.-M. Törmäletho, et al. (2013). The use of registers in the context of EU-SILC: challenges and opportunities. Luxembourg, Publications Office of the European Union. 
Lohmann, H. (2009). "Welfare States, labour market institutions and the working poor: A comparative analysis of 20 European countries " European Sociological Review 25(4): 489-504.

Lohmann, H. and I. Marx, Eds. (2018). Handbook on In-Work Poverty. Cheltenham, UK, Edvard Elgar Publishing.

Maitre, B., B. Nolan, et al. (2012). "Low pay, in-work poverty and economic vulnerability: a comparative analysis using EU-SILC." The Manchester School 80(1): 99-116.

Mannheim, K. (1952 [1928]). The problem of generations. Essays on the sociology of knowledge. P. Kecskemeti. London, Routledge and Kegan Paul: 276-322.

Marx, I. and B. Nolan (2012). In-work poverty. GINI Discussion Paper 51.

McKnight, A., K. Stewart, et al. (2016). Low pay and in-work poverty: preventative measures and preventative approaches. Brussels, European Commission. Directorate-General for Employment, Social Affairs and Inclusion Directorate Social Affairs. Unit C1 - Social investment Strategy.

Moller, S., E. Huber, et al. (2003). "Determinants of relative poverty in advanced capitalist democracies." American Sociological Review 68(1): 22-51.

OECD (2011). Doing better for families. Paris, Organisation for Economic Cooperation and Development.

OECD (2015). Non-standard work, job polarisation and inequality. In It Together: Why Less Inequality Benefits All. Paris, Organisation for Economic Cooperation and Development.

Ponthieux, S. (2010). In-work poverty in the EU. Eurostat Methodologies and Working Papers. Luxembourg, Eurostat.

Ponthieux, S. (2018). Gender and in-work poverty. Handbook on In-Work Poverty. H. Lohmann and I. Marx. Cheltenham, UK, Edward Elgar Publishing.

Rastrigina, O. and A. Vereshchagna (2015). Secondary earners and fiscal policies in Europe. Luxembourg, European Commission - Directorate-General for Justice.

Ray, K., P. Sissons, et al. (2014). Employment, pay and poverty. Evidence and policy review. York, Joseph Rowntree Foundation.

Sissons, P., A. Green, et al. (2018). "Linking the sectoral employment structure and household poverty in the United Kingdom." Work, Employment and Society 32(6): 1078-1098.

Sutherland, H. and F. Figari (2013). "EUROMOD: the European Union tax-benefit microsimulation model." International Journal of Microsimulation 6(1): 4-26.

Thomas, A. and P. O'Reilly (2016). The impact of tax and benefit systems on the workforce participation incentives of women. OECD Taxation Working Paper No. 29. Paris, Organisation for Economic Cooperation and Development.

Van Lancker, W. (2011). "The European world of temporary employment: Gendered and poor?" European Societies 14(1): 83-111. 


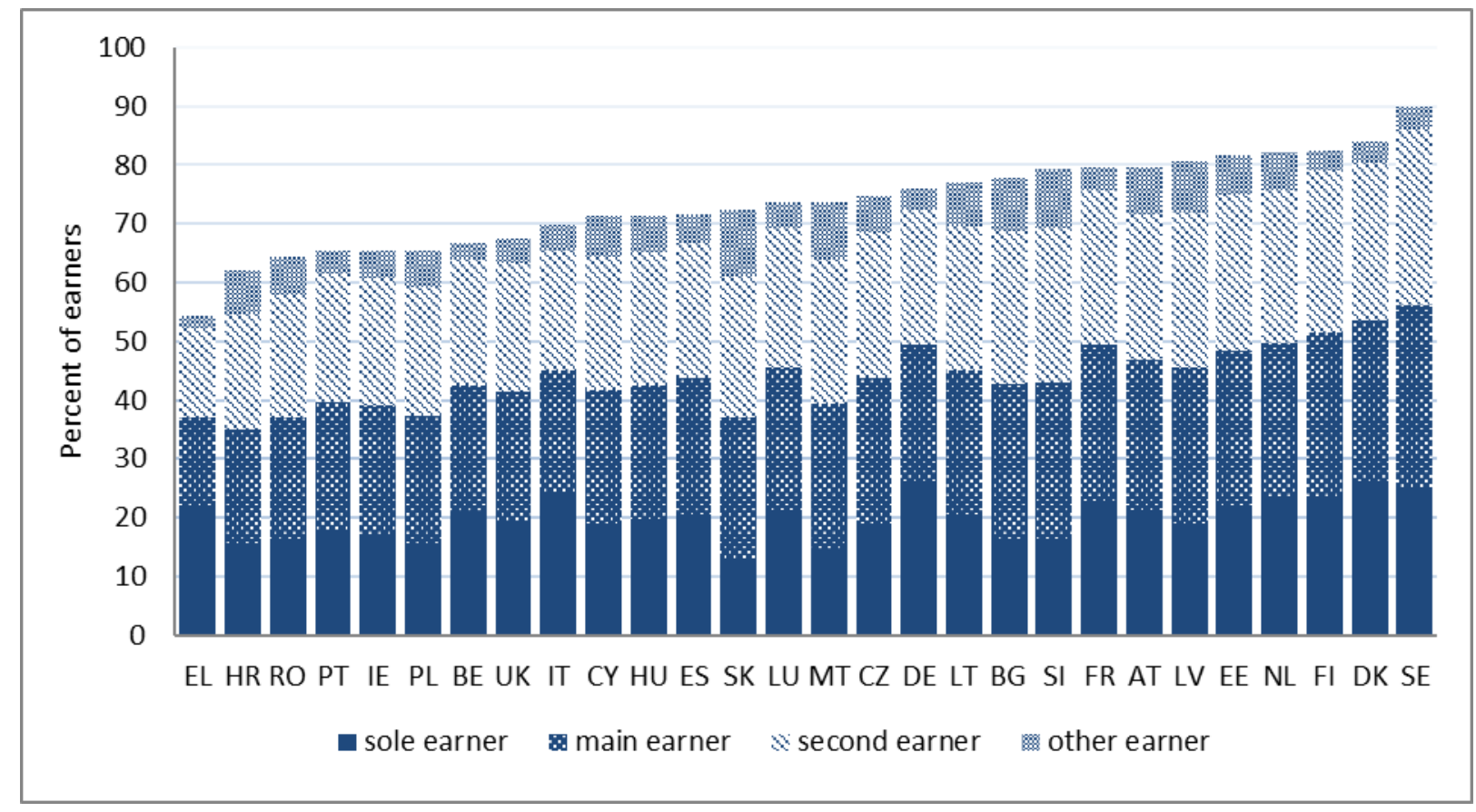

Figure 1: Distribution of working individuals by earnership status, percent of working age individuals (18-64 years old)

Note: Countries are ordered by the total percentage of working individuals among the working age individuals. Here and in other figures the following acronyms are used: Belgium (BE), Bulgaria (BG), Czechia (CZ), Denmark (DK), Germany (DE), Estonia (EE), Ireland (IE), Greece (EL), Spain (ES), France (FR), Croatia (HR), Italy (IT), Cyprus (CY), Latvia (LV), Lithuania (LT), Luxembourg (LU), Hungary (HU), Malta (MT), Netherlands (NL), Austria (AT), Poland (PL), Portugal (PT), Romania (RO), Slovenia (SI), Slovakia (SK), Finland (FI), Sweden (SE).

See: https://ec.europa.eu/eurostat/statistics-explained/index.php/Glossary:Country_codes. 


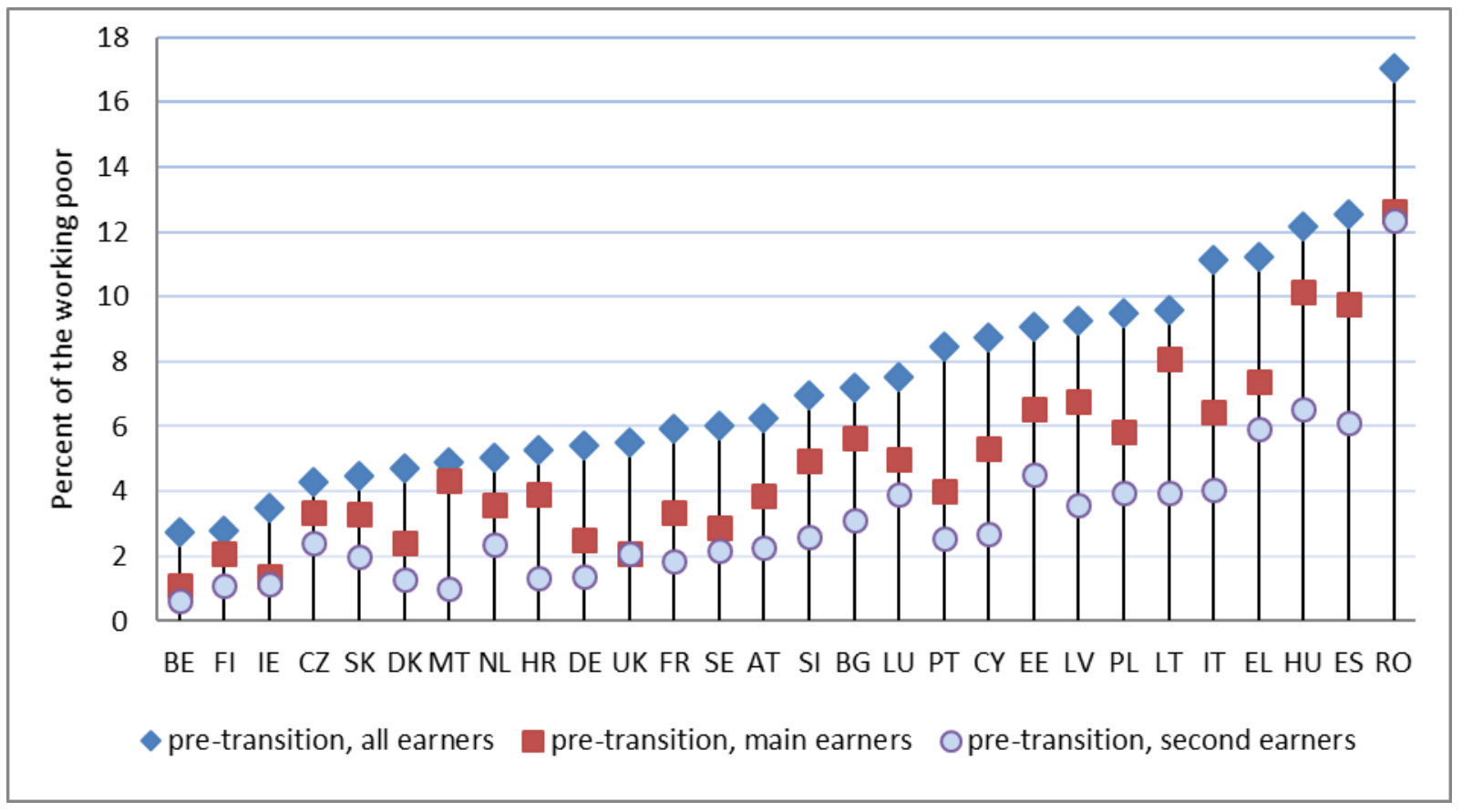

Figure 2: In-work poverty rates for all earners, main and second earners, percent

Note: Countries are ordered by the pre-transition in-work poverty rates for all earners. See Figure 1 for the meaning of country acronyms. 


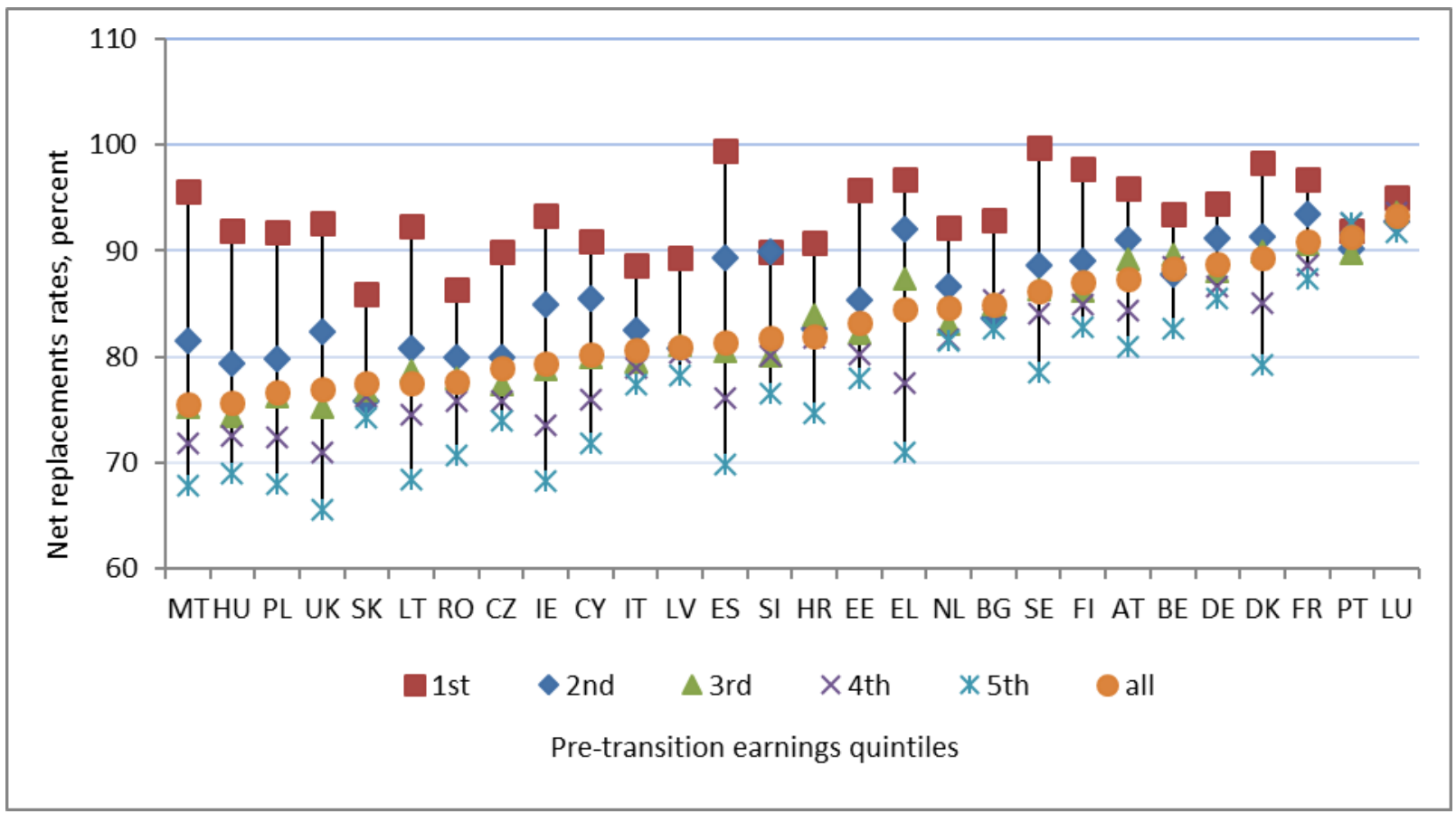

Figure 3: Net replacement rates (NRRs) of second earners by pre-transition earnings quintiles, percent

Note: Countries are ordered by the NRRs for all second earners. See Figure 1 for the meaning of country acronyms. 


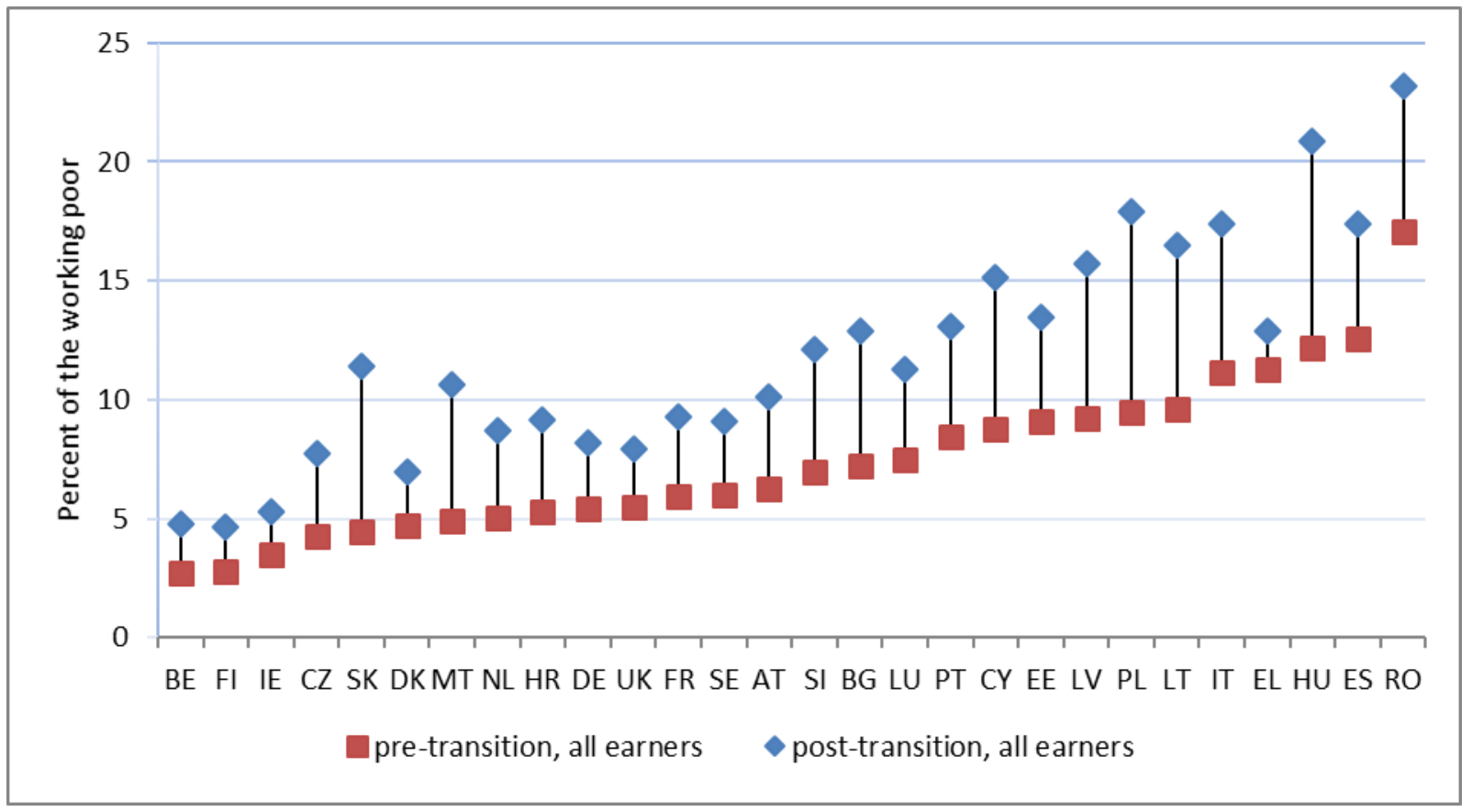

Figure 4: Pre- and post-transition in-work poverty rates in the EU and the UK, percent

Note: Countries are ordered by the pre-transition in-work poverty rates. See Figure 1 for the meaning of country acronyms. 
Table 1: Logistic regression of the probability of being working poor, pooled dataset for all countries with country fixed effects

\begin{tabular}{|c|c|c|c|c|c|c|c|c|}
\hline & \multicolumn{4}{|c|}{ Model 1} & \multicolumn{4}{|c|}{ Model 2} \\
\hline & B & se & DYDX & se & B & se & DYDX & se \\
\hline main earner & $-0.8326 * * *$ & $(0.0613)$ & $-0.0410 * * *$ & $(0.0030)$ & $-1.0459 * * *$ & $(0.1343)$ & $-0.0510 * * *$ & $(0.0066)$ \\
\hline secondary earner & $-2.1834 * * *$ & $(0.0750)$ & $-0.1075^{* * *}$ & $(0.0037)$ & $-1.2291 * * *$ & $(0.1522)$ & $-0.0600 * * *$ & $(0.0075)$ \\
\hline other earner & $-2.1549 * * *$ & $(0.1318)$ & $-0.1061 * * *$ & $(0.0065)$ & $-2.6460 * * *$ & $(0.4198)$ & $-0.1291 * * *$ & $(0.0205)$ \\
\hline female & $-0.2272 * * *$ & $(0.0377)$ & $-0.0112 * * *$ & $(0.0019)$ & $-0.2221 * * *$ & $(0.0526)$ & $-0.0108 * * *$ & $(0.0026)$ \\
\hline age, years & $-0.0542 * * *$ & $(0.0120)$ & $-0.0027 * * *$ & $(0.0006)$ & -0.0126 & $(0.0128)$ & -0.0006 & $(0.0006)$ \\
\hline age squared, years/10 & $0.0050 * * *$ & $(0.0014)$ & $0.0002^{* * * *}$ & $(0.0001)$ & 0.0003 & $(0.0015)$ & 0.0000 & $(0.0001)$ \\
\hline partnered & $0.6049 * * *$ & $(0.0444)$ & $0.0298^{* * * *}$ & $(0.0022)$ & $0.9234 * * *$ & $(0.0513)$ & $0.0450 * * *$ & $(0.0025)$ \\
\hline low-skilled & $0.7235^{* * * *}$ & $(0.0414)$ & $0.0356^{* * *}$ & $(0.0021)$ & $0.5468 * * *$ & $(0.0567)$ & $0.0267 * * *$ & $(0.0028)$ \\
\hline self-employed & $0.9759^{* * *}$ & $(0.0390)$ & $0.0481^{* * *}$ & $(0.0019)$ & $0.8031^{* * *}$ & $(0.0582)$ & $0.0392 * * *$ & $(0.0028)$ \\
\hline part-time job & $1.6385^{* * * *}$ & $(0.0452)$ & $0.0807 * * *$ & $(0.0023)$ & $1.7125^{* * *}$ & $(0.0631)$ & $0.0835^{* * *}$ & $(0.0031)$ \\
\hline low-paid job & $2.4315^{* * * *}$ & $(0.0380)$ & $0.1198 * * *$ & $(0.0018)$ & $2.3713 * * *$ & $(0.0529)$ & $0.1157 * * *$ & $(0.0025)$ \\
\hline number of children $0-3$ years & -0.0015 & $(0.0609)$ & -0.0001 & $(0.0030)$ & -0.0147 & $(0.0615)$ & -0.0007 & $(0.0030)$ \\
\hline number of children $3-5$ years & $0.2155^{* * * *}$ & $(0.0474)$ & $0.0106^{* * *}$ & $(0.0023)$ & $0.2218 * * *$ & $(0.0480)$ & $0.0108 * * *$ & $(0.0023)$ \\
\hline number of children 6-12 years & $0.2797 * * *$ & $(0.0265)$ & $0.0138^{* * * *}$ & $(0.0013)$ & $0.2689 * * *$ & $(0.0270)$ & $0.0131 * * *$ & $(0.0013)$ \\
\hline number of children 13-17 years & $0.7771 * * *$ & $(0.0297)$ & $0.0383^{* * *}$ & $(0.0015)$ & $0.7708 * * *$ & $(0.0302)$ & $0.0376^{* * *}$ & $(0.0015)$ \\
\hline number of earners & $-0.4950 * * *$ & $(0.0526)$ & $-0.0244 * * *$ & $(0.0026)$ & $-0.4958 * * *$ & $(0.0511)$ & $-0.0242 * * *$ & $(0.0025)$ \\
\hline tenant & $0.3132 * * *$ & $(0.0420)$ & $0.0154^{* * *}$ & $(0.0021)$ & $0.3223^{* * *}$ & $(0.0425)$ & $0.0157 * * *$ & $(0.0021)$ \\
\hline ln of financial capital & $-0.0668 * * *$ & $(0.0048)$ & $-0.0033 * * *$ & $(0.0002)$ & $-0.0615 * * *$ & $(0.0048)$ & $-0.0030 * * *$ & $(0.0002)$ \\
\hline
\end{tabular}




\begin{tabular}{|c|c|c|c|c|c|c|c|c|}
\hline & \multicolumn{4}{|c|}{ Model 1} & \multicolumn{4}{|c|}{ Model 2} \\
\hline & B & se & DYDX & se & B & se & DYDX & se \\
\hline second earner*female & & & & & $-0.2532 *$ & $(0.1016)$ & $-0.0123^{*}$ & $(0.0050)$ \\
\hline second earner*partnered & & & & & $-1.1419 * * *$ & $(0.1087)$ & $-0.0557 * * *$ & $(0.0053)$ \\
\hline second earner*low-skilled & & & & & $0.2003+$ & $(0.1115)$ & $0.0098+$ & $(0.0054)$ \\
\hline second earner*self-employed & & & & & $0.5294 * * *$ & $(0.0949)$ & $0.0258 * * *$ & $(0.0046)$ \\
\hline second earner*part-time & & & & & $-0.3523 * * *$ & $(0.1026)$ & $-0.0172 * * *$ & $(0.0050)$ \\
\hline second earner*low-paid & & & & & $-0.1900+$ & $(0.0974)$ & $-0.0093+$ & $(0.0047)$ \\
\hline main earner*female & & & & & $0.3292 * * *$ & $(0.0884)$ & $0.0161 * * *$ & $(0.0043)$ \\
\hline main earner*partnered & & & & & $-0.7176 * * *$ & $(0.0992)$ & $-0.0350 * * *$ & $(0.0048)$ \\
\hline main earner*low-skilled & & & & & $0.4279 * * *$ & $(0.0981)$ & $0.0209 * * *$ & $(0.0048)$ \\
\hline main earner*self-employed & & & & & -0.0125 & $(0.0910)$ & -0.0006 & $(0.0044)$ \\
\hline main earner*part-time & & & & & $0.4290 * * *$ & $(0.1161)$ & $0.0209 * * *$ & $(0.0057)$ \\
\hline main earner*low-paid & & & & & $0.4880 * * *$ & $(0.0874)$ & $0.0238 * * *$ & $(0.0043)$ \\
\hline other earner*female & & & & & 0.1638 & $(0.1901)$ & 0.0080 & $(0.0093)$ \\
\hline other earner*partnered & & & & & $-1.1828 * * *$ & $(0.2004)$ & $-0.0577 * * *$ & $(0.0097)$ \\
\hline other earner*low-skilled & & & & & $0.6912^{*}$ & $(0.2855)$ & $0.0337 *$ & $(0.0139)$ \\
\hline other earner*self-employed & & & & & $1.3280 * * *$ & $(0.1857)$ & $0.0648 * * *$ & $(0.0091)$ \\
\hline other earner*part-time & & & & & $-0.7472 * * *$ & $(0.2086)$ & $-0.0364 * * *$ & $(0.0102)$ \\
\hline other earner*low-paid & & & & & 0.2088 & $(0.2892)$ & 0.0102 & $(0.0141)$ \\
\hline
\end{tabular}

Notes: Robust standard errors in parentheses; $* * * \mathrm{p}<0.001,{ }^{* *} \mathrm{p}<0.01, * \mathrm{p}<0.05,+\mathrm{p}<0.1 ; \mathrm{N}$ : All earners aged 18-64 years with non-zero earnings 
Table 2: Logistic regression of the probability of being a working poor before and after the transition of second earners to unemployment, pooled dataset for all countries with country fixed effects

\begin{tabular}{|c|c|c|c|c|c|c|c|c|c|c|c|c|}
\hline & \multicolumn{4}{|c|}{ pre-transition in-work poverty } & \multicolumn{8}{|c|}{ post-transition in-work poverty } \\
\hline & \multicolumn{4}{|c|}{ Model 1} & \multicolumn{4}{|c|}{ Model 2} & \multicolumn{4}{|c|}{ Model 3} \\
\hline & B & se & DYDX & se & B & se & DYDX & se & B & se & DYDX & se \\
\hline \multicolumn{13}{|l|}{ net replacement rate of secondary } \\
\hline earners, $\%$ & & & & & $-0.0272 * * *$ & $(0.0026)$ & $-0.0014 * * *$ & $(0.0001)$ & $-0.0896 * * *$ & $(0.0032)$ & $-0.0030 * * *$ & $(0.0001)$ \\
\hline female & 0.0525 & $(0.0740)$ & 0.0015 & $(0.0022)$ & $0.3240 * * *$ & $(0.0555)$ & $0.0169 * * *$ & $(0.0029)$ & $0.3300^{* * *}$ & $(0.0688)$ & $0.0110^{* * *}$ & $(0.0023)$ \\
\hline age, years & -0.0002 & $(0.0248)$ & -0.0000 & $(0.0007)$ & 0.0029 & $(0.0189)$ & 0.0002 & $(0.0010)$ & 0.0256 & $(0.0250)$ & 0.0009 & $(0.0008)$ \\
\hline age squared, years $/ 10$ & -0.0001 & $(0.0029)$ & -0.0000 & $(0.0001)$ & -0.0006 & $(0.0022)$ & -0.0000 & $(0.0001)$ & -0.0025 & $(0.0029)$ & -0.0001 & $(0.0001)$ \\
\hline partnered & 0.0444 & $(0.1038)$ & 0.0013 & $(0.0031)$ & 0.1307 & $(0.0813)$ & 0.0068 & $(0.0042)$ & -0.0771 & $(0.1027)$ & -0.0026 & $(0.0034)$ \\
\hline low-skilled & $0.8438^{* * *}$ & $(0.0891)$ & $0.0249 * * *$ & $(0.0027)$ & $1.0960 * * *$ & $(0.0611)$ & $0.0572 * * *$ & $(0.0033)$ & $1.2811 * * *$ & $(0.0778)$ & $0.0426^{* * *}$ & $(0.0027)$ \\
\hline self-employed & $1.0455^{* * * *}$ & $(0.0711)$ & $0.0309 * * *$ & $(0.0021)$ & $0.9913^{* * *}$ & $(0.0580)$ & $0.0517 * * *$ & $(0.0030)$ & $0.5650^{* * *}$ & $(0.0767)$ & $0.0188^{* * *}$ & $(0.0026)$ \\
\hline part-time job & $1.6530^{* * * *}$ & $(0.1002)$ & $0.0488 * * *$ & $(0.0031)$ & $1.5699 * * *$ & $(0.0833)$ & $0.0819^{* * *}$ & $(0.0044)$ & $1.3186^{* * *}$ & $(0.1076)$ & $0.0439 * * *$ & $(0.0036)$ \\
\hline low-paid job & $2.6988 * * *$ & $(0.0755)$ & $0.0797 * * *$ & $(0.0024)$ & $2.5878^{* * *}$ & $(0.0640)$ & $0.1350^{* * *}$ & $(0.0032)$ & $2.3168^{* * *}$ & $(0.0841)$ & $0.0771 * * *$ & $(0.0029)$ \\
\hline number of children $0-3$ years & 0.0549 & $(0.1278)$ & 0.0016 & $(0.0038)$ & -0.1528 & $(0.0945)$ & -0.0080 & $(0.0049)$ & -0.1353 & $(0.1200)$ & -0.0045 & $(0.0040)$ \\
\hline number of children $3-5$ years & $0.3330^{* * * *}$ & $(0.0928)$ & $0.0098 * * *$ & $(0.0027)$ & $0.2983^{* * *}$ & $(0.0684)$ & $0.0156^{* * *}$ & $(0.0036)$ & $0.3748^{* * *}$ & $(0.0861)$ & $0.0125^{* * *}$ & $(0.0029)$ \\
\hline number of children 6-12 years & $0.3331 * * *$ & $(0.0539)$ & $0.0098 * * *$ & $(0.0016)$ & $0.2500 * * *$ & $(0.0416)$ & $0.0130 * * *$ & $(0.0022)$ & $0.2534 * * *$ & $(0.0533)$ & $0.0084 * * *$ & $(0.0018)$ \\
\hline number of children 13-17 years & $0.7707 * * *$ & $(0.0546)$ & $0.0228 * * *$ & $(0.0016)$ & $0.7980 * * *$ & $(0.0408)$ & $0.0416^{* * *}$ & $(0.0021)$ & $0.7872 * * *$ & $(0.0511)$ & $0.0262 * * *$ & $(0.0017)$ \\
\hline number of earners & $-1.0389 * * *$ & $(0.0646)$ & $-0.0307 * * *$ & $(0.0019)$ & $-1.2785 * * *$ & $(0.0535)$ & $-0.0667 * * *$ & $(0.0027)$ & $-1.3916^{* * *}$ & $(0.0726)$ & $-0.0463 * * *$ & $(0.0024)$ \\
\hline tenant & $0.4072 * * *$ & $(0.0921)$ & $0.0120 * * *$ & $(0.0027)$ & $0.3588^{* * *}$ & $(0.0718)$ & $0.0187 * * *$ & $(0.0038)$ & $0.3803^{* * *}$ & $(0.0879)$ & $0.0126^{* * *}$ & $(0.0030)$ \\
\hline
\end{tabular}




\begin{tabular}{|c|c|c|c|c|c|c|c|c|c|c|c|c|}
\hline & \multicolumn{4}{|c|}{ pre-transition in-work poverty } & \multicolumn{8}{|c|}{ post-transition in-work poverty } \\
\hline & \multicolumn{4}{|c|}{ Model 1} & \multicolumn{4}{|c|}{ Model 2} & \multicolumn{4}{|c|}{ Model 3} \\
\hline & $\mathrm{B}$ & se & DYDX & se & $\mathrm{B}$ & se & DYDX & se & $\mathrm{B}$ & se & DYDX & se \\
\hline ln of financial capital & $-0.0688 * * *$ & $(0.0096)$ & $-0.0020 * * *$ & $(0.0003)$ & $-0.0771 * * *$ & $(0.0081)$ & $-0.0040 * * *$ & $(0.0004)$ & $-0.0848 * * *$ & $(0.0111)$ & $-0.0028 * * *$ & $(0.0004)$ \\
\hline constant & $-3.5780^{* * *}$ & $(0.5695)$ & & & 0.2252 & $(0.4809)$ & & & $4.8593^{* * *}$ & $(0.5808)$ & & \\
\hline "Observations & 82,777 & & & & 82,777 & & & & 79,472 & & & \\
\hline
\end{tabular}

Notes:

Robust standard errors in parentheses

$* * * \mathrm{p}<0.001, * * \mathrm{p}<0.01, * \mathrm{p}<0.05,+\mathrm{p}<0.1$

$\mathrm{N}$ : Model 1 - main/other earners in households with 2+ earners before the transition; Model 2 - main/other earners in households with 2+ earners after the transition; Model 3 - main/other earners in households with $2+$ earners after the transition that were not poor before the transition 


\section{SUPPLEMENTAL MATERIAL}

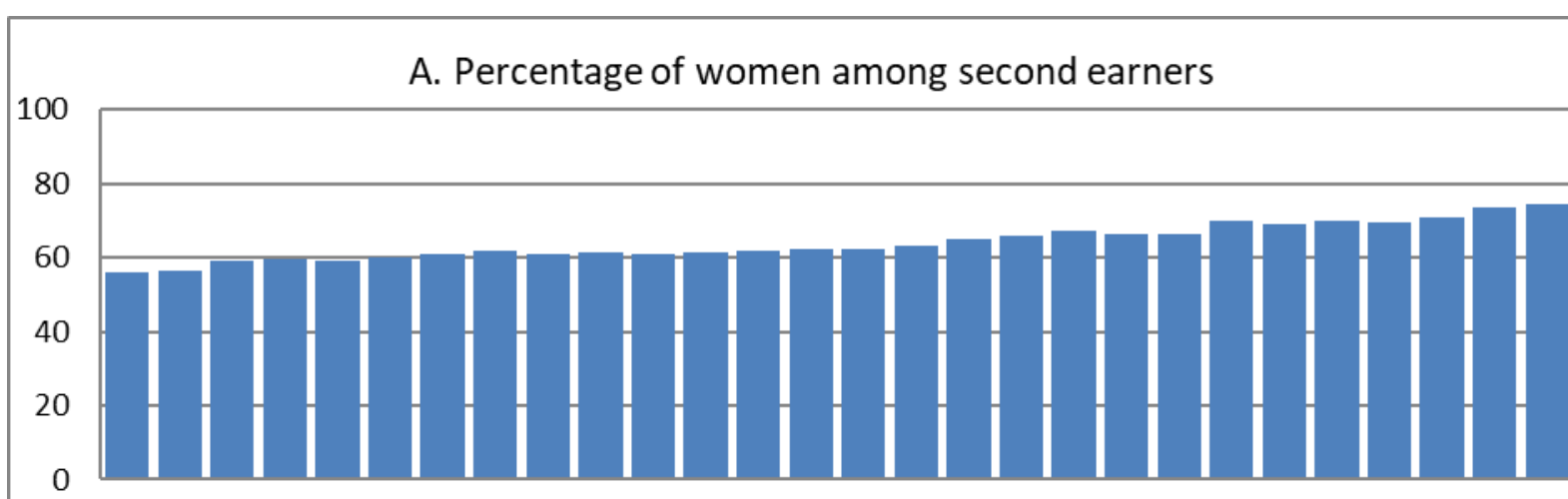

MT SI LV PL hR LT IT BG ES CY IE EL RO HU SK EE LU FR FI UK PT SE DK AT BE CZ NL DE

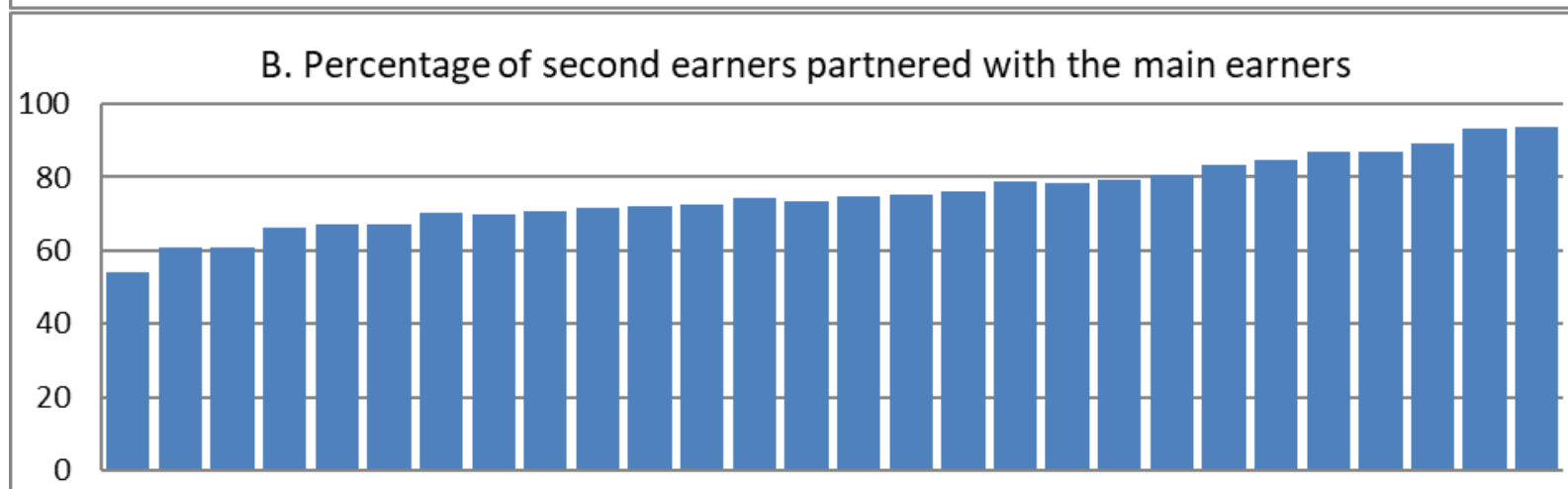

MT HR SK BG LV PL IT RO HU LT EL SI AT ES PT CY IE EE CZ UK LU NL DE FR BE DK FI SE

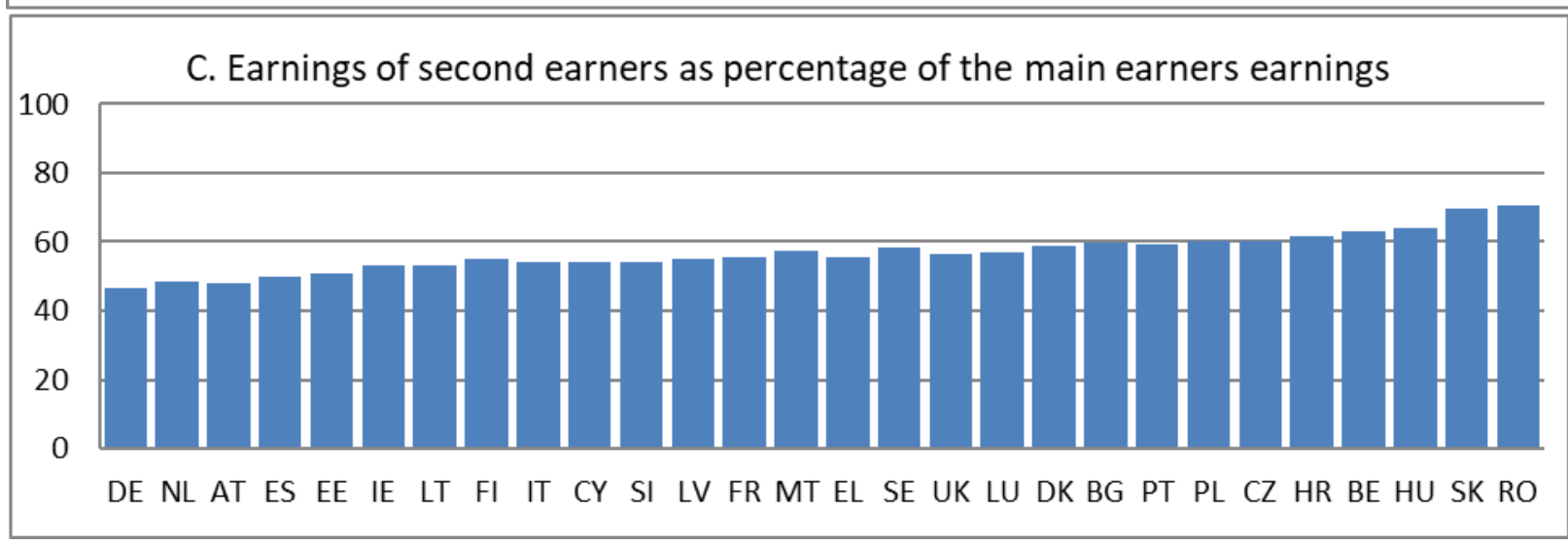

Figure A1: Characteristics of second earners: gender, partnership status and earnings, percent

Note: Countries are ordered by the percentages of second earners with the above characteristics. Here and in other figures the following acronyms are used: Belgium (BE), Bulgaria (BG), Czechia (CZ), Denmark (DK), Germany (DE), Estonia (EE), Ireland (IE), Greece (EL), Spain (ES), France (FR), Croatia (HR), Italy (IT), Cyprus (CY), Latvia (LV), Lithuania (LT), Luxembourg (LU), Hungary (HU), Malta (MT), Netherlands (NL), Austria (AT), Poland (PL), Portugal (PT), Romania (RO), Slovenia (SI), Slovakia (SK), Finland (FI), Sweden (SE). See: https://ec.europa.eu/eurostat/statistics-explained/index.php/Glossary:Country_codes. 


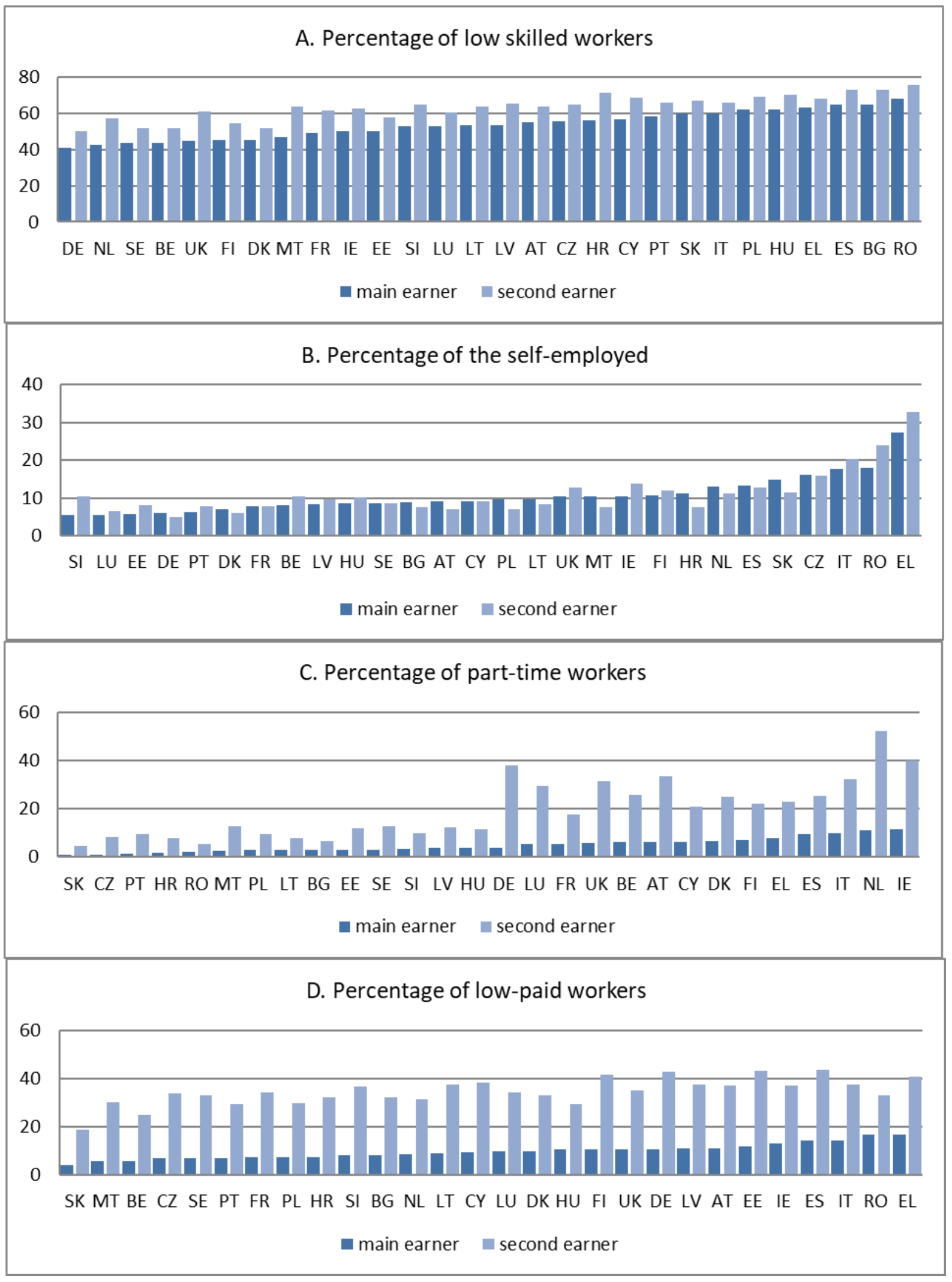

Figure A2: Labour market characteristics of second earners and main earners: prevalence of low skills, self-employment, part-time employment and low pay, percent

Note: Countries are ordered by the percentages of main earners with the above characteristics. See Figure A1 for the meaning of country acronyms. 


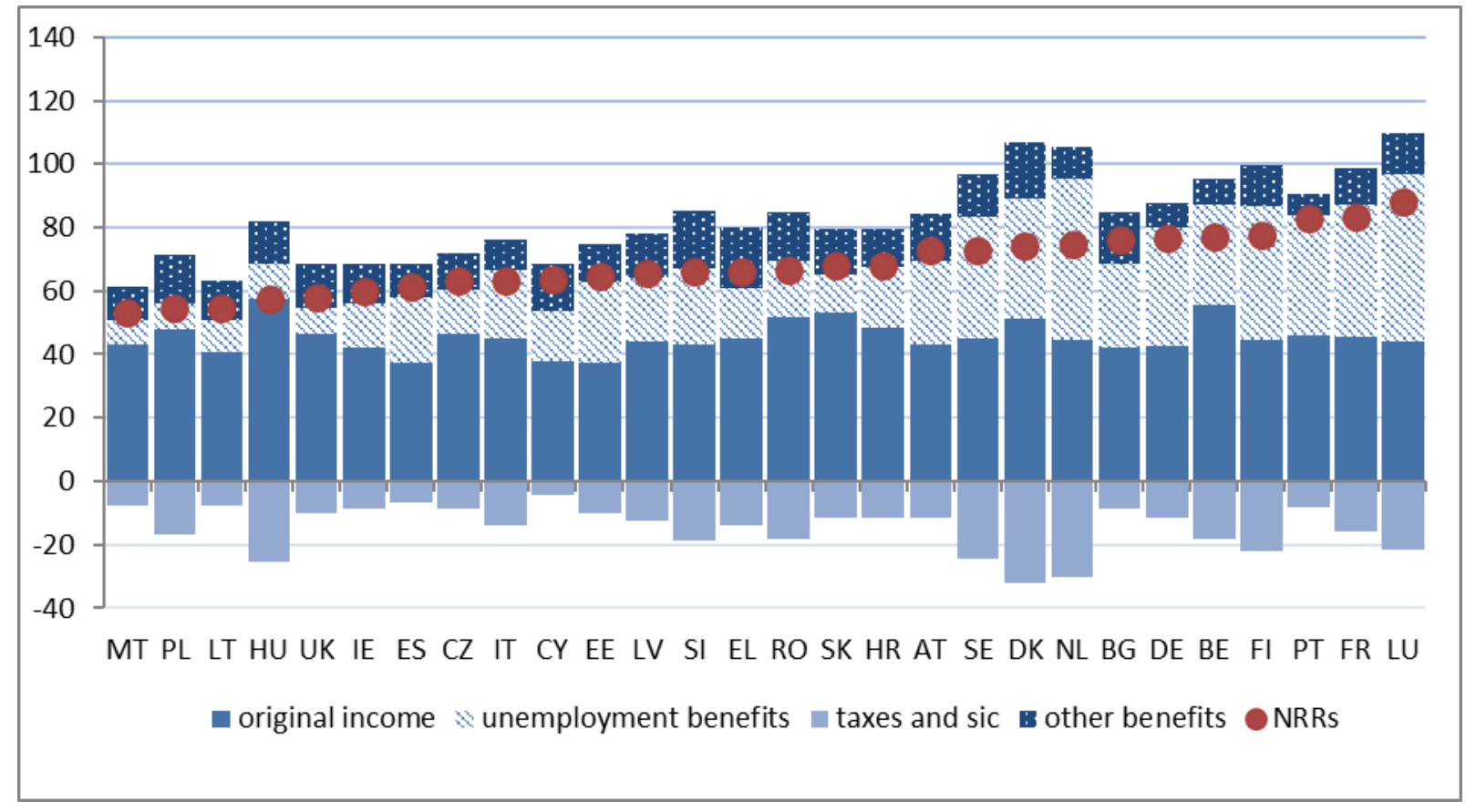

Figure A3: Decomposition of mean net replacement rates of main earners, percent

Note: Countries are ordered by mean net replacement rates of main earners. See Figure A1 for the meaning of country acronyms.

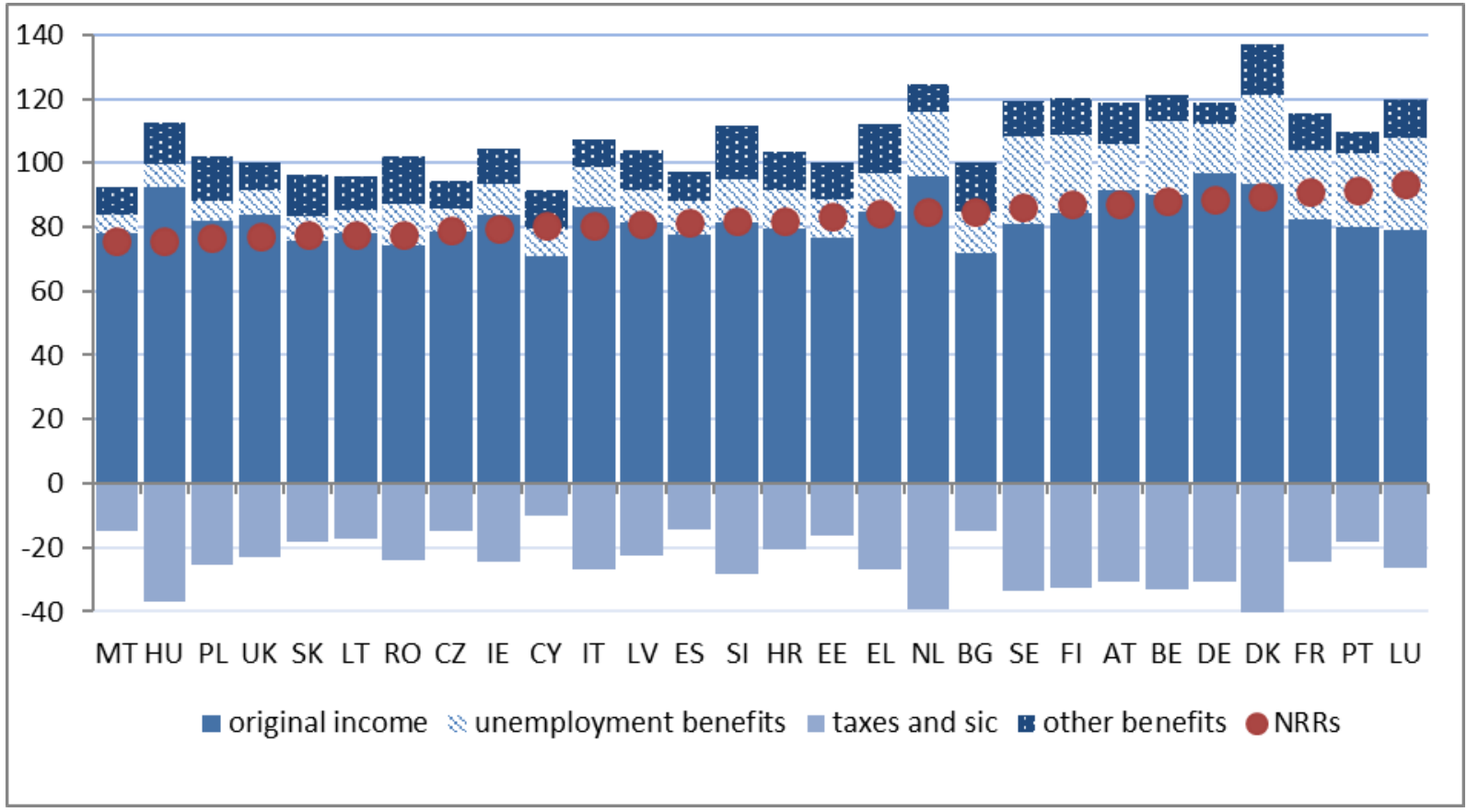

Figure A4: Decomposition of mean net replacement rates of second earners, percent

Note: Countries are ordered by mean net replacement rates of second earners. See Figure A1 for the meaning of country acronyms. 


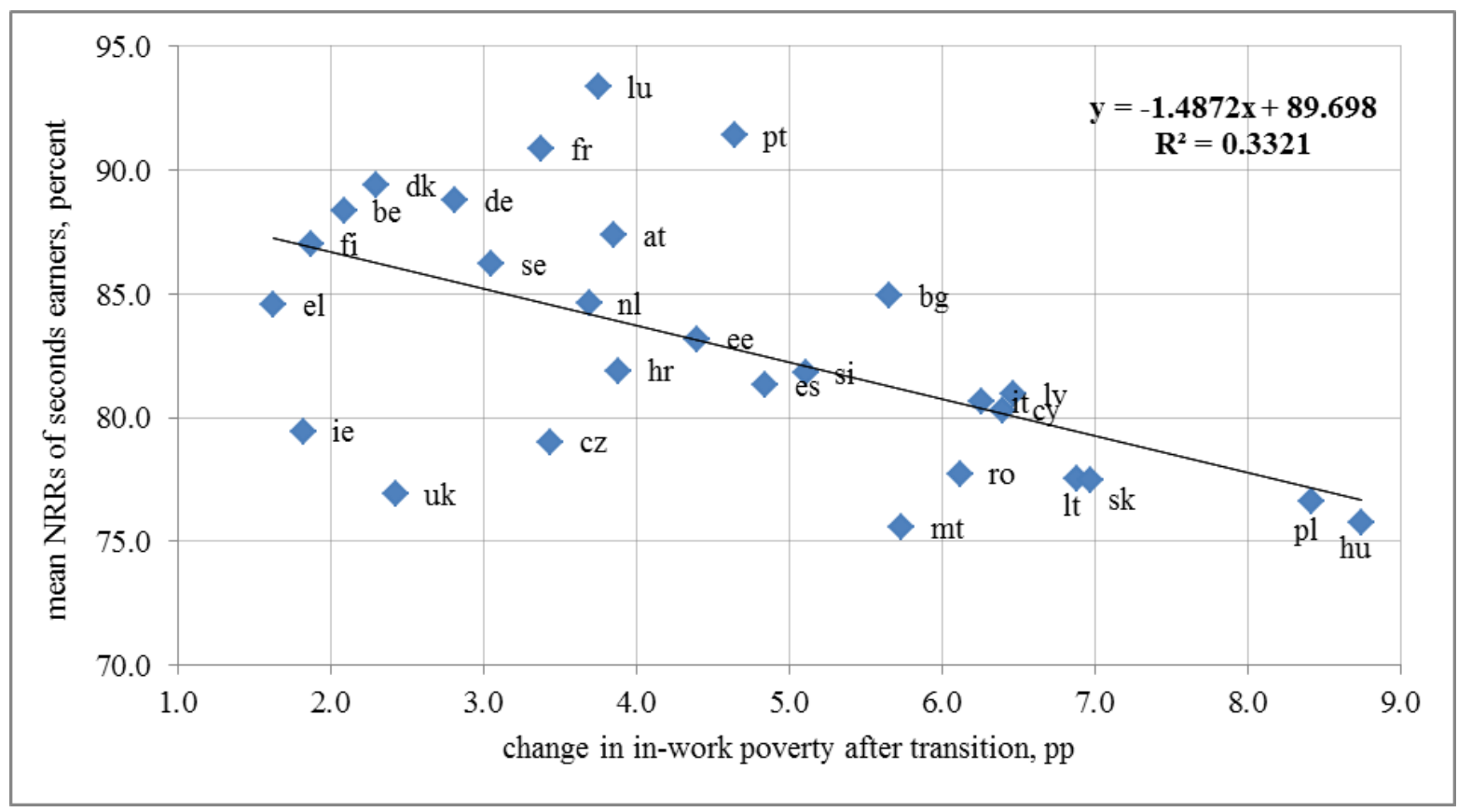

Figure A5: Mean NRRs of second earners vs. changes in in-work poverty rates due to transition

Note: See Figure A1 for the meaning of country acronyms.

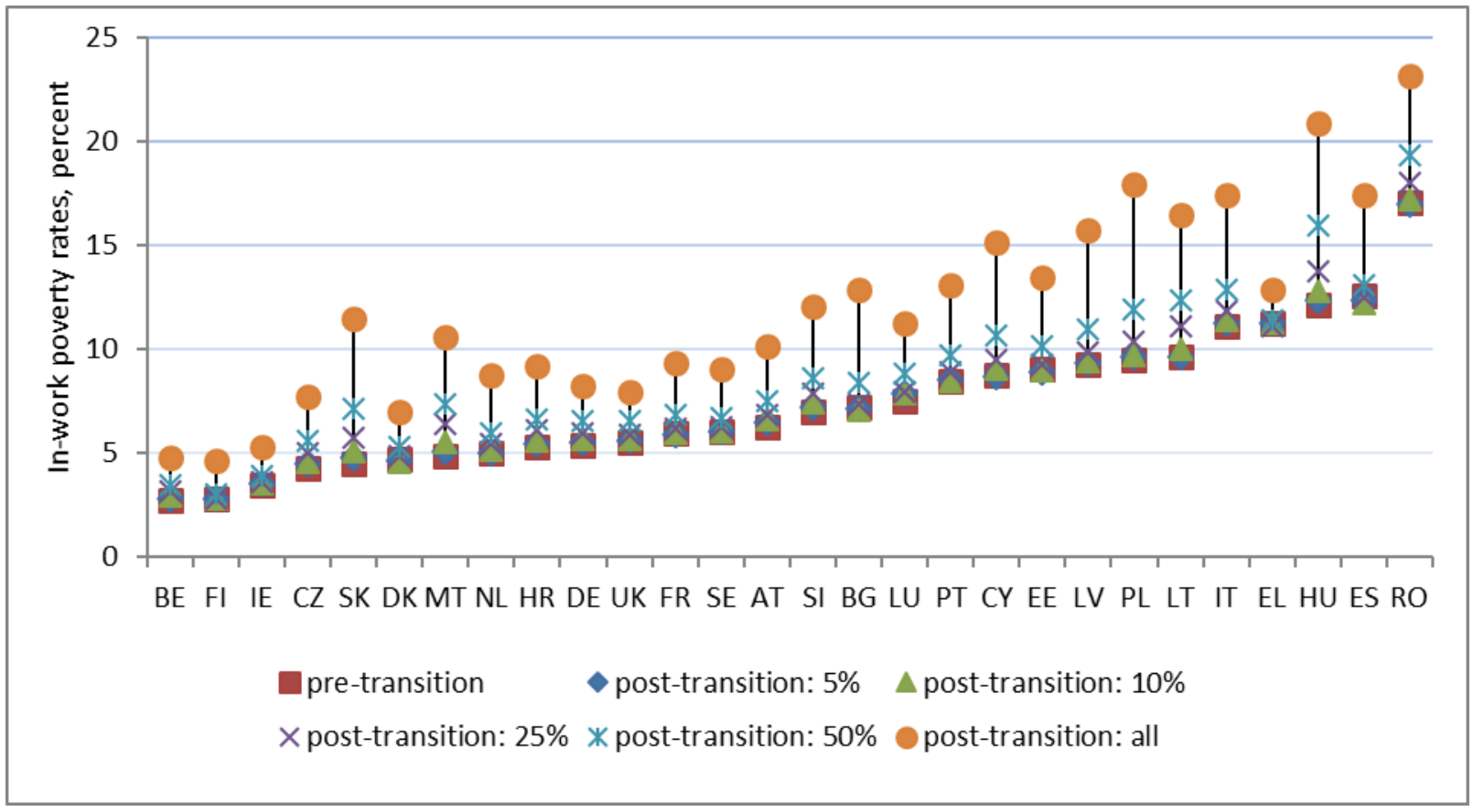

Figure A6: Pre- and post-transition in-work poverty rates under different types of shocks,

$$
\text { percent of working age population }
$$

Note: Countries are ordered by pre-transition in-work poverty rates. See Figure A1 for the meaning of country acronyms. 


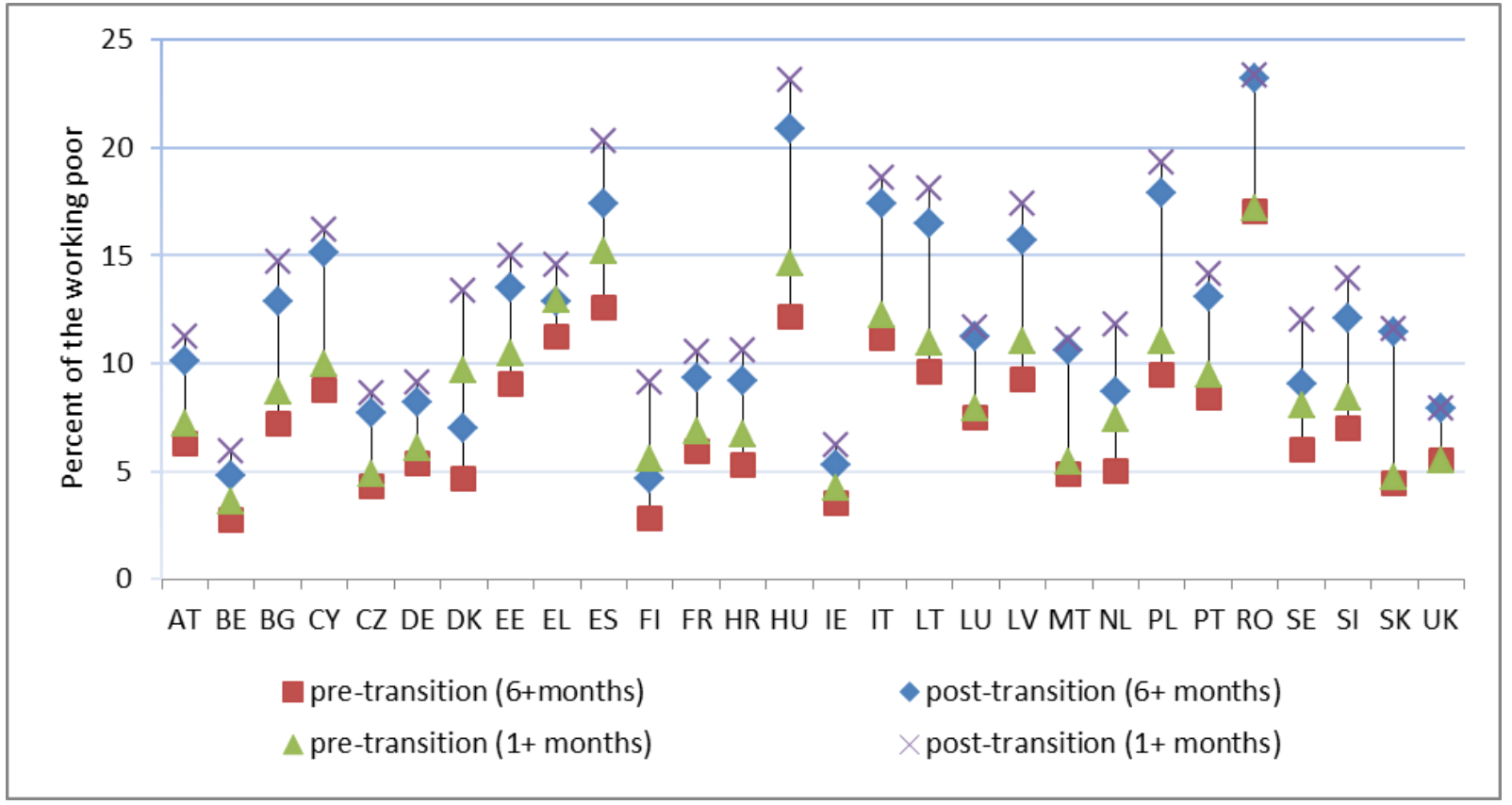

Figure A7: Pre- and post-transition in-work poverty rates under different definitions of employment, percent of working age population

Note: Countries are ordered alphabetically. See Figure A1 for the meaning of country acronyms.

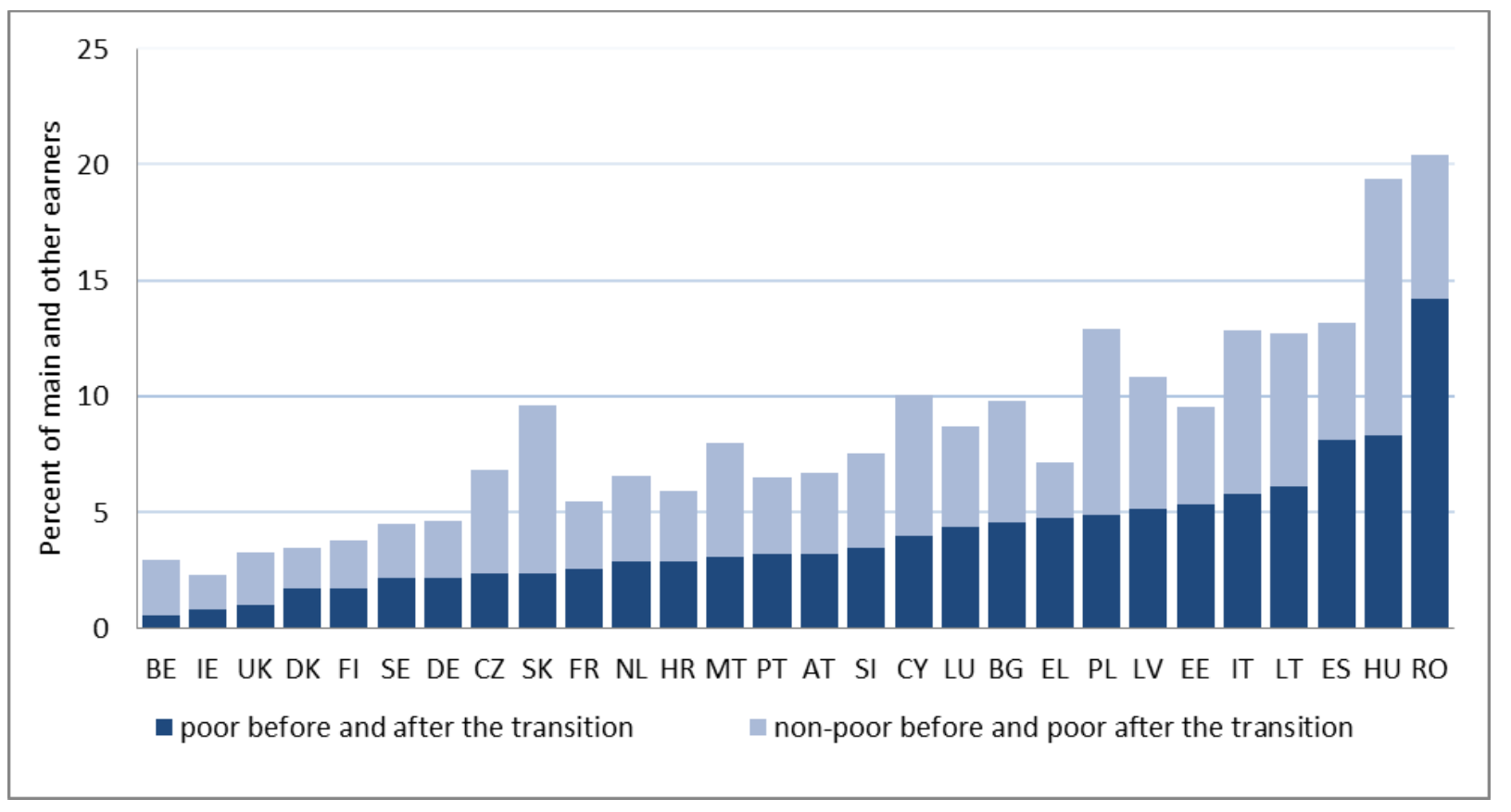

Figure A8: Pre- and post-transition in-work poverty status of earners, percent of earners in multi-earner households

Note: Countries are ordered by the percentage of earners who were poor before and after the transition of second earners to unemployment. See Figure A1 for the meaning of country acronyms. 
Table A1: Descriptive statistics for variables used in the logistic regression of the probability of being working poor, pooled dataset for $28 \mathrm{EU}$ countries

\begin{tabular}{|c|c|c|c|c|}
\hline & mean & sd & $\min$ & $\max$ \\
\hline main earner & 0.368 & & 0 & 1 \\
\hline secondary earner & 0.319 & & 0 & 1 \\
\hline other earner & 0.0506 & & 0 & 1 \\
\hline female & 0.474 & & 0 & 1 \\
\hline age, years & 43.42 & 11.13 & 18 & 64 \\
\hline age squared, years/10 & 200.9 & 95.06 & 32.40 & 409.6 \\
\hline partnered & 0.720 & & 0 & 1 \\
\hline low-skilled & 0.591 & & 0 & 1 \\
\hline self-employed & 0.133 & & 0 & 1 \\
\hline part-time job & 0.127 & & 0 & 1 \\
\hline low-paid job & 0.181 & & 0 & 1 \\
\hline number of children $0-3$ years & 0.0953 & 0.318 & 0 & 4 \\
\hline number of children 3-5 years & 0.116 & 0.349 & 0 & 3 \\
\hline number of children 6-12 years & 0.283 & 0.597 & 0 & 7 \\
\hline number of children $13-17$ years & 0.224 & 0.508 & 0 & 6 \\
\hline number of earners & 1.827 & 0.738 & 1 & 14 \\
\hline tenant & 0.164 & & 0 & 1 \\
\hline ln of financial capital & 3.507 & 4.645 & -2.996 & 22.54 \\
\hline
\end{tabular}

Observations

216,355

Notes: N: All earners aged 18-64 years with non-zero earnings 
Table A2: Descriptive statistics for variables used in the logistic regression of the probability of being a working poor before and after the transition of second earners to unemployment, pooled dataset for $28 \mathrm{EU}$ countries

\begin{tabular}{|c|c|c|c|c|c|c|c|c|c|c|c|c|}
\hline & \multicolumn{4}{|c|}{ pre-transition in-work poverty } & \multicolumn{8}{|c|}{ post-transition in-work poverty } \\
\hline & Model 1 & & & & Model 2 & & & & Model 3 & & & \\
\hline & mean & sd & $\min$ & $\max$ & mean & sd & $\min$ & $\max$ & mean & sd & $\min$ & $\max$ \\
\hline female & 0.337 & & 0 & 1 & 0.337 & & 0 & 1 & 0.335 & & 0 & 1 \\
\hline age, years & 43.06 & 11.14 & 18 & 64 & 43.06 & 11.14 & 18 & 64 & 43.11 & 11.14 & 18 & 64 \\
\hline age squared, years/10 & 197.8 & 93.65 & 32.40 & 409.6 & 197.8 & 93.65 & 32.40 & 409.6 & 198.2 & 93.74 & 32.40 & 409.6 \\
\hline partnered & 0.833 & & 0 & 1 & 0.833 & & 0 & 1 & 0.834 & & 0 & 1 \\
\hline low-skilled & 0.553 & & 0 & 1 & 0.553 & & 0 & 1 & 0.541 & & 0 & 1 \\
\hline self-employed & 0.120 & & 0 & 1 & 0.120 & & 0 & 1 & 0.110 & & 0 & 1 \\
\hline part-time job & 0.0656 & & 0 & 1 & 0.0656 & & 0 & 1 & 0.0603 & & 0 & 1 \\
\hline low-paid job & 0.117 & & 0 & 1 & 0.117 & & 0 & 1 & 0.0970 & & 0 & 1 \\
\hline number of children $0-3$ years & 0.105 & 0.332 & 0 & 4 & 0.105 & 0.332 & 0 & 4 & 0.105 & 0.332 & 0 & 4 \\
\hline number of children $3-5$ years & 0.128 & 0.364 & 0 & 3 & 0.128 & 0.364 & 0 & 3 & 0.127 & 0.362 & 0 & 3 \\
\hline number of children $6-12$ years & 0.306 & 0.613 & 0 & 7 & 0.306 & 0.613 & 0 & 7 & 0.302 & 0.608 & 0 & 6 \\
\hline number of children 13-17 years & 0.247 & 0.527 & 0 & 4 & 0.247 & 0.527 & 0 & 4 & 0.240 & 0.520 & 0 & 4 \\
\hline number of earners & 2.219 & 0.702 & 1 & 14 & 2.219 & 0.702 & 1 & 14 & 2.228 & 0.696 & 1 & 14 \\
\hline
\end{tabular}




\begin{tabular}{|c|c|c|c|c|c|c|c|c|c|c|c|c|}
\hline & \multicolumn{4}{|c|}{ pre-transition in-work poverty } & \multicolumn{8}{|c|}{ post-transition in-work poverty } \\
\hline & Model 1 & & & & Model 2 & & & & Model 3 & & & \\
\hline & mean & $\mathrm{sd}$ & $\min$ & $\max$ & mean & $\mathrm{sd}$ & $\min$ & $\max$ & mean & $\mathrm{sd}$ & $\min$ & $\max$ \\
\hline tenant & 0.130 & & $\begin{array}{l}0 \\
-\end{array}$ & 1 & 0.130 & & $\begin{array}{l}0 \\
-\end{array}$ & 1 & 0.128 & & 0 & 1 \\
\hline In of financial capital & 3.639 & 4.686 & 2.996 & 22.14 & 3.639 & 4.686 & 2.996 & 22.14 & 3.718 & 4.712 & -2.996 & 22.14 \\
\hline net replacements rates, $\%$ & & & & & 83.09 & 11.11 & 4.490 & 165.8 & 82.74 & 10.65 & 4.680 & 149.9 \\
\hline Observations & 82,777 & & & & 82,777 & & & & $\overline{779,472}$ & & & \\
\hline
\end{tabular}

Notes:

$\mathrm{N}$ : Model 1 - main/other earners in households with 2+ earners before the transition; Model 2 - main/other earners in households with 2+ earners after the transition; Model 3 - main/other earners in households with 2+ earners after the transition that were not poor before the transition 